\title{
The Role of Heavy Metals in Plant Response to Biotic Stress
}

\author{
Iwona Morkunas 1,*, Agnieszka Woźniak ${ }^{1}$, Van Chung Mai ${ }^{1,2}$, Renata Rucińska-Sobkowiak ${ }^{3}$ \\ and Philippe Jeandet ${ }^{4}$ (D)
}

1 Department of Plant Physiology, Poznań University of Life Sciences, Wołyńska 35, 60-637 Poznań, Poland; agnieszkam.wozniak@gmail.com (A.W.); chungmv@vinhuni.edu.vn (V.C.M.)

2 Department of Plant Physiology, Vinh University, Le Duan 182, Vinh City, Vietnam

3 Department of Plant Ecophysiology, Adam Mickiewicz University, Umultowska 89, 61-614 Poznań, Poland; renatar@amu.edu.pl

4 Research Unit “Induced Resistance and Plant Bioprotection”, UPRES EA 4707, Department of Biology and Biochemistry, Faculty of Sciences, University of Reims, P.O. Box 1039, 0251687 Reims CEDEX, France; philippe.jeandet@univ-reims.fr

* Correspondence: iwona.morkunas@gmail.com or iwona.morkunas@mail.up.poznan.pl; Tel.: +48-61-846-6040; Fax: +48-61-848-7179

Received: 25 August 2018; Accepted: 8 September 2018; Published: 11 September 2018

\begin{abstract}
The present review discusses the impact of heavy metals on the growth of plants at different concentrations, paying particular attention to the hormesis effect. Within the past decade, study of the hormesis phenomenon has generated considerable interest because it was considered not only in the framework of plant growth stimulation but also as an adaptive response of plants to a low level of stress which in turn can play an important role in their responses to other stress factors. In this review, we focused on the defence mechanisms of plants as a response to different metal ion doses and during the crosstalk between metal ions and biotic stressors such as insects and pathogenic fungi. Issues relating to metal ion acquisition and ion homeostasis that may be essential for the survival of plants, pathogens and herbivores competing in the same environment were highlighted. Besides, the influence of heavy metals on insects, especially aphids and pathogenic fungi, was shown. Our intention was also to shed light on the relationship between heavy metals deposition in the environment and ecological communities formed under a strong selective pressure.
\end{abstract}

Keywords: hormesis; toxic effect; heavy metals; biotic stressors; cross-talk; plant defence responses

\section{Introduction}

Heavy metals belong to the group of the most dangerous pollutants in ecotoxicology regarding their high toxicity and their significant amounts released into the environment as a result of natural and anthropogenic processes [1-4]. This situation creates a need for research focusing on the assessment of the impact of heavy metals on living organisms and other elements of the natural environment. Heavy metals might be poisonous depending on the metal type, its oxidation state, $\mathrm{pH}$, concentration, duration and so forth, leading to the death of organisms. The toxicity of a specific substance depends on a variety of factors, including how much of the substance organisms are exposed to, how they are exposed and for how long. It is documented that chemicals at a low dose may have beneficial effects that is termed hormesis and at a high dose, harmful effects. In this review, we focus on the impact of heavy metals at hormetic and toxic doses on plant responses and how their presence in the surrounding environment affects the response of plants to biotic stressors such as insects, especially aphids and pathogenic fungi playing a definite role in the trophic chain (Table S1 and Table 1). Additionally, the effect of heavy metals on insects, especially aphids and fungi were demonstrated 
(Tables 2 and 3). It has been documented that air and soil pollution, including heavy metals can affect the plants-insects/plants-pathogens relationships directly or indirectly, can be toxic or cause hormesis effect and change their behaviour and metabolism [5-7].

Understanding the mechanisms underlying plant resistance or tolerance of plants to abiotic and biotic stress factors is extremely important in the era of global warming, where the mobility of pollutants in the environment increases. Because plants are prone to various abiotic and biotic stresses, exposure of plants to one stress affects their response during the next stress leading to enhanced defence mechanisms to a later stress. This phenomenon called as "priming" results in a faster and stronger induction of basal defence mechanisms upon subsequent biotic stress factors [8]. This is an example of the occurrence of "metabolic memory" in higher plants [9,10], some stress "memory" or "stress imprinting" defined as genetic or biochemical modifications [11]. Moreover, it requires less energy expenditure than defence directly induced by insect feeding or infection caused by pathogens. Ahmad et al. [12] reported that priming-inducing stimuli can provide more effective basal resistance, especially when an earlier defence response precedes immune suppression by the invading pathogen. Convergence points in abiotic and biotic stress signalling networks were also shown [13]. On the other hand, the extremely interesting hypotheses of Poschenrieder and co-workers [14,15] such as elemental defence hypothesis, trade-off hypothesis, metal therapy and metal-induced fortification showed that metal ions may be factors that induce chemical defences against herbivores and infective microorganisms. Suitable intracellular concentrations of essential metal ions are not only required for the optimal growth and development of plants and their enemies but also for pathogen virulence and plant defence. In the presence of different toxic levels of metal ions, the degree of metal avoidance and/or tolerance of the interacting organisms will determine the response of plant host-insect/plant host-pathogen.

Of all the known elements, more than $75 \%$ exhibit the properties of metals. The metals were divided into two groups due to their density (specific atomic mass). Thus, light metals present a density of less than $5 \mathrm{~g} / \mathrm{cm}^{3}$ and heavy metals are defined as elements having specific weights higher than $5 \mathrm{~g} / \mathrm{cm}^{3}$ [16]. A number of them (e.g., cobalt-Co, iron-Fe, manganese-Mn, molybdenum-Mo, nickel-Ni, zinc- $\mathrm{Zn}$, copper- $\mathrm{Cu}$ ) are essential micronutrients required for normal growth and take part in redox reactions, electron transfers and other important metabolic processes in plants, whereas, others such as lead- $\mathrm{Pb}$, cadmium- $\mathrm{Cd}$, chromium- $\mathrm{Cr}$, mercury- $\mathrm{Hg}$, arsenic-As and so forth are potentially highly toxic for plants $[17,18]$. Heavy metals in the environment have various origins: they arise from natural processes such as rock weathering, volcanic eruptions, forest fires, soil-forming processes. However, the most important sources are anthropogenic processes. Large areas of land are contaminated with heavy metals resulting from mines, industries, urban activities and agricultural practices [19,20]. In terrestrial ecosystems, heavy metals mainly enter into the plants from soil but they may also originate from the external atmosphere surrounding plants [21]. One of the most serious problems related to metal toxicology is the contamination of soils with heavy metals, because they exhibit very high stability in soils and lack of biodegradability [22]. Therefore, metals present in soils can easily enter into the food chain [23]. According to the United States Environmental Protection Agency (UEPA), heavy metals are listed as priority pollutants. In terms of environmental risks, $\mathrm{Pb}, \mathrm{Hg}, \mathrm{As}$ and $\mathrm{Cd}$ are ranked as the first, second, third and sixth, respectively, in the list of US Agency for Toxic Substances and Disease Registry (ATSDR) [22].

The effects of metals in soils are very complex and these effects are dependent on chemical processes such as adsorption-desorption, complexation-dissociation, oxidation-reduction, ion exchange and transporters. Adsorption-desorption and complexation-dissociation reactions mainly affect metal activity in soil, while oxidation-reduction can also change metal valence [24]. The bioavailability and toxicity of metals in soils are significantly influenced by $\mathrm{pH}$ conditions [2,25]. Excessive concentrations of heavy metals inhibit physiological processes such as photosynthesis, respiration, transpiration rates, $\mathrm{N}$-metabolism and mineral nutrition, cell elongation, decrease in biomass and consequently can cause plant death [26]. Plant responses to heavy metals are observed 
as changes in redox status, the level of signal molecules, the activity of antioxidant system enzymes, membrane permeability, cysteine content, glutathione (GSH) and phytochelatin (PCs) contents, protein content, expression of genes encoding pathogenesis-related (PR) proteins and genes encoding enzymes of the flavonoid biosynthesis pathway, level of phenolics and so forth (see references in Table S1). The impact of heavy metals is strongly related to their doses, the plant species and the plant developmental phase as well as environmental factors characteristic for a given climate zone. Toxic effects of metals on plants are generally well documented in the literature [27-37] but research on the responses of organisms, including plants, insects and fungal pathogens to heavy metals at the hormetic doses are less known and at the same time extremely interesting [38,39].

\section{Hormesis as A Biological Phenomenon in the Context of Organisms' Defence against Heavy Metals}

In the published literature, the impact of heavy metals on the reduction of plant growth and modification of root morphology was widely presented [35,40-43]. Inhibition of the growth of plants under the effect of heavy metals leads to a decrease in yield, which is associated with the inhibition of most of the basic life processes of plants. However, at a low metal dose in the substrate, the opposite reaction can be observed [44]. In the present review, we focus on the progress of research into hormetic responses in terms of growth of plants, insects and fungi. The hormesis phenomenon has been observed in many organisms in response to different stress factors, that is, chemical, physical and biological. As mentioned above, already in the 16th century, Paracelsus wrote that various toxic substances may be beneficial in small quantities [45]. Calabrese and Baldwin [46] reported that the concept of chemical hormesis originate over a century ago from the research of Schulz [47], who observed a stimulation of both the growth and the respiration of yeast at low metal doses. Later, this concept was supported by other studies known as the Arndt-Schulz law. Moreover, in the opinion of some authors [46], hormetic effects are observed not only for growth but also during development, reproduction, survival and longevity. These authors reported that hormetic effects may also be closely related to numerous metabolic and physiological responses such as metallothionein synthesis, DNA and RNA syntheses, mitosis, oxygen consumption, photosynthesis rate, tissue regeneration, immune response, stress protein synthesis, seed germination and so forth. According to Damelin et al. [48], hormetic activity is a specific cellular response and most likely, a stress response to low but harmful levels of toxic agents. In another definition, hormesis refers to a process whereby a sublethal stressor renders an organism resistant to a subsequent stress. Additionally, an assessment of the toxicological basis of the hormetic dose-response relationship including implications for risk assessment, was provided by Calabrese [49]. In turn, a detailed assessment of the occurrence of hormesis within plants was also reported by Calabrese and Blain [50]. These authors presented the most prevalent chemical classes, including heavy metals and physical agents in the general hormesis database useful for plant studies. We summarized in Table S1, a list of various plant species, where the hormesis effect caused by various heavy metals has been observed. Additionally, information concerning the changes observed in various physiological and biochemical indicators of plants were also presented in Table S1.

For example, the hormesis effect of aluminium ( $\mathrm{Al})$ on the growth, development and biomass production of plants such as rice, tea, coffee, Melastoma malabathricum, soybean and maize was also recorded [44,51-56]. Moreover, numerous studies have reported the hormesis effect caused by Cd for plant species such as Gypsophila fastigiata, Sedum alfredii, Viola baoshanensis, Lonicera japonica, Dianthus carhusianorum, Solanum melongena, Arabis paniculata, Brassica juncea, Salsola kali, Spirodela polyrrhiza, Arabis paniculata [57-66]. This effect was also caused by As in the case of Spirodela polyrrhiza L. [65]. Besides, numerous experiments with chromium (Cr) revealed hormetic growth in the cases of Eichhornia crassipes [67], Salsola kali L. [68], Lemna minuta [69], Allium cepa L. [70] and Capsicium annum L. [71]. An hormetic response was observed as well, in the case of elements such as lanthanum (La) for Lonicera japonica [72], Oryza sativa L. [73] and Arabis paniculata [66], Pb for Pisum sativum [35], Brassica pekinensis [74] and Dianthus carthusianorum [60], Hg for Anthyllis vulneraria [75] and Helianthus tuberosus [76], palladium 
(Pd) for P. sativum L. [77], platinum (Pt) for Arabidopsis thaliana [78], uranium (U) for Schizachyrium scoparium [79], Zn for Thlaspi caerulescens [80], Sedum alfredii [57] and Arabis paniculata [66].

Additionally, an hormesis effect was also demonstrated in the case of insects. For example, hormesis as induced by $\mathrm{Cd}$ was reported in an insect model, such as the queen blowfly, Phormia regina, where low levels of dietary $\mathrm{Cd}$ caused a significant increase of the pupation rate of larvae [81]. Results of the above-mentioned research indicate the need to evaluate the impact of environmental stressors at different concentration ranges and during the entire life cycle. In turn, an hormetic effect was observed for insect survival of Folsomia candida under the influence of copper (Cu) [82]. Uranium (U) as well, caused hormetic responses in the case of earthworms (Eisenia fetida), which are the most abundant terrestrial species, playing an important role in maintaining the ecological function of soil [83]. Eisenia andrei (Oligochaeta: Lumbricidae), the potworm Enchytraeus crypticus (Oligochaeta: Enchytraeidae) and the springtail Folsomia candida (Collembola: Isotomidae) were also used as invertebrate test organisms in studying the hormesis effect in insects [83]. In turn, the glutathione $S$-transferase was involved in the induction of methylmercury (MeHg)-hormesis in the case of Caenorhabditis elegans, a free-living (non-parasitic) nematode [84]. These studies were performed to search whether MeHg induces hormesis, that is, whereby a sub lethal exposure to MeHg rendered C. elegans resistant to a subsequent exposure to this organometal. Previous studies of the same authors reported neurotoxic resistance of C. elegans to $\mathrm{MeHg}$ [85].

Nickel (Ni)-contamination of soils containing earthworms caused a hormesis response of the soil microorganisms that displayed a stimulation of microbial biomass $C$ and soil basal respiration (SBR) [86]. Moreover, the hormesis effect has also been shown to accelerate pest population growth, insecticide resistance development, pesticide-induced arthropod pest resurgences, leading to interesting applications for the management of beneficial insects [87]. Environmental factors and other factors affect the amplitude of a wide range of hormetic responses [88]. For example, availability of nutrients, temperature, light and factors such as symbiosis, density-dependent factors, time, have an influence on hormetic responses.

In turn, a few studies reported hormetic responses to fungi. As shown by Calabrese and Baldwin [89], the assessment of the toxic effect of substances on fungi has a long history referring to the physiology, the growth and the reproduction of fungi. Already, Raulin [90] revealed that the sulphates of $\mathrm{Zn}$ and Fe markedly stimulated the growth of the fungus Aspergillus [46]. Raulin's studies were aimed at showing quantitative relationships between disinfection agents and fungi. Establishment of fungal dose-response data near the turn of the 19th/20th centuries was carried out by investigators such as Stevens [91], Clark [92-94] and Duggar [95], who worked on the effect of numerous agents on fungal germination and/or mycelium growth and fruiting using wide metal dosage ranges. Later research, for example, Collin-Hansen et al. [96] demonstrated the toxic and the hormetic effects of the potential emissions from a $\mathrm{Zn}$ smelter to induce oxidative damages to DNA and lipids in Boletus edulis. These authors observed negative trends between the concentration of some metals $(\mathrm{Cd}, \mathrm{Zn}, \mathrm{Cu}$ and $\mathrm{Hg}$ ) and apurinic/apyrimidinic sites or lipid hydroperoxides in the reference king bolete group. It has been indicated that in B. edulis, low concentrations of $\mathrm{Hg}$, caused relationships of an hormetic nature such as an increase in metabolism, immunity and growth. Lefcort et al. [97] revealed that low levels of heavy metal pollution can have positive effects for populations of one snail species and one periphyton species. It should also be mentioned that a highly significant contribution to the history of hormesis was afforded by the research on yeast performed by Schulz [47].

\section{Influence of Heavy Metals in the Response of Plants to Biotic Stressors and Cross-Talk between Heavy Metals and Biotic Stressors}

Plants in the course of evolution demonstrate adaptation or tolerance to various abiotic and biotic stress factors. Responses of plants to environmental stresses involve constitutive defences as well as stress-inducible reactions. Stimulation of important tolerance pathways, such as enhancement of antioxidant enzymes activity, osmolyte accumulation, induction of membrane-localized transporters 
for efficient compartmentation of deleterious ions and accumulation of essential elements against pests or pathogens is also an area that has been intensively studied. Plants have developed mechanisms for ion homeostasis that enable them to cope with a certain limited excess of heavy metals [98]. Potentially toxic but essential metals required for normal growth have to be absorbed and distributed to different parts of the plant. Hall and Williams [99] reported that chaperons, chelators and specific transmembrane transporters have evolved. In plants non-adapted to given environmental conditions, that are challenged with ion excess, an enhanced biosynthesis of complexing substances such as phytochelatins, metallothioneins and/or organic acids can occur. It has been proven that in the case of arsenic (As) tolerance, normal constitutive tolerance as well as adaptive hypertolerance are based on phytochelatin-mediated sequestration $[100,101]$. In turn, in the case of copper $(\mathrm{Cu})$ tolerance, it has been found that high $\mathrm{Cu}$ tolerance in a metallicolous population of Silene vulgaris was associated with high transcript levels of the metallothionein-like gene $S v M T 2 b$. Abundance and tissue distribution of efficient, specific, efflux and transport systems for metal ions and chelators seem fundamental traits for high-level tolerance in plants [102].

Some metal cations are also important for plant nutrition. Metals such as $\mathrm{Cu}, \mathrm{Fe}, \mathrm{Zn}$ and $\mathrm{Mn}$ act as important cofactors for many enzymes and are essential for both mitochondrial and chloroplast functions. However, when supplied in excess, these essential cations can become toxic like other heavy metals. To maintain micronutrient metal homeostasis and to cope with the deleterious effects of nonessential heavy metals, plants have developed a complex network of metal uptake, chelation, trafficking and storage processes. Metal transporters are required to maintain metal homeostasis in plant cells [20,99]. As reported by Ahanger et al. [103], plants sensitive to high levels of metals cannot survive in unfavourable environmental conditions, despite the induction of tolerance mechanisms. It has been documented that the plant responses to stress are dependent on the tissue or the organ affected by a given stress factor [104]. For example, transcriptional responses to stress are tissue or cell specific in roots and are quite different depending on the stress factor [105]. In addition, the level and the duration of the stress (acute vs. chronic) can have a significant effect on the complexity of the response. However, it should be noted that, in the environment, metals do not act as a single factor but simultaneous or subsequent effects of several other stress factors are observed. Here, our goal is to provide literature data evidencing phenomena such as cross-tolerance and cross-resistance in the case of heavy metal and biotic stress factor interactions [106-109]. Plant resistance mechanisms to heavy metals and biotic stress factors such as pathogenic fungi, bacteria and invertebrates, including insects are well known. However, progress in the field of abiotic and biotic stress signal transduction pathways and research results concerning metal hyperaccumulating plants make this topic still very interesting [106,110-116].

Responses to heavy metal excess in sensitive plants can resemble elicitor-induced defence reactions [117]. As an example of the negative cross-talk existing between abiotic stress (heavy metal) and biotic stress responses, the study by Llugany et al. [118] has indicated that $\mathrm{Cd}$ accumulation induces salicylic acid (SA) production in Thymus praecox but diminishes the plants' ability to induce SA as a defence signal in response to attack by Erysiphe cruciferarum. Another study by Fones et al. [119] has shown that some pathogen-induced defences such as callose deposition and pathogenesis-related (PR) protein gene induction appears to be absent in Noccaea caerulescens, although the tested plants retained the ability to produce SA as a response to infection. This study also showed that the ability of Pseudomonas syringae to infect $N$. caerulescens plants grown on low concentrations of $\mathrm{Zn}$ was dependent on a functional type III secretion system (T3SS), a pathogenicity mechanism used by P. syringae to disable plant defences. This suggests that certain defence mechanisms that are suppressed by T3SS-secreted effector proteins remain functional in this plant. On the contrary, cross talk in down-stream signalling events has been well documented. As one of few candidates for such an early interaction, the cell wall associated kinase 1 (WAK1) is required for Arabidopsis resistance to P. syringae; plants over-expressing WAK1 exhibit enhanced Al tolerance [120]. Signal transduction pathways of biotic stresses offer multiple points of interaction with heavy metal stress signalling. 
Stress-activated increases in mitogen-activated protein kinases (MAPKs), phytohormones such as jasmonic acid (JA), salicylic acid (SA) and ethylene (ET) are in fact major cross points of interactions between pathogen-elicited responses and specific toxic effects of heavy metals. For example, exposure of Medicago sativa seedlings to excessive concentrations of $\mathrm{Cu}$ or $\mathrm{Cd}$ activates different MAPKs such as SIMK, MMK2, MMK3 and SAMK, thus suggesting that plants respond to heavy metal stress through the induction of several distinct MAPK pathways and that excess amounts of $\mathrm{Cu}$ and $\mathrm{Cd}$ induce different cellular signalling mechanisms [111]. Another screen for Cd-responsive genes identified the Arabidopsis MAPKKK MEKK1 to be transcriptionally induced by high concentrations of Cd [121]. JA is one of the typically phytohormones involved in signalling and induced as a result of cell damage by herbivores and necrotrophic pathogens but $\mathrm{Cu}$ and $\mathrm{Cd}$ were also found to induce JA in both A. thaliana and Phaseolus coccineus plants [122]. JA is connected to the toxic action of these two heavy metals in plants, differentially reacting to exogenous JA and possessing variable dynamics depending on the studied plants as well as their growth stage. The Ni tolerant capability mediating SA signalling pathway in Thlaspi plants was constitutively elevated and the ability to maintain high levels of reduced glutathione seems to be a key factor for both metal tolerance and pathogen resistance [123]. The mentioned above examples prove that plant hormones may play central roles in the tolerance of plants to changing environmental conditions. Moreover, the synergistic or antagonistic hormone actions and the coordinated regulation of hormone biosynthetic pathways in association with the induction of other defence responses, play crucial roles in the adaptation of plants to stresses [124].

Contamination of the environment with heavy metals causes their significant accumulation in organisms at various levels of the food chain [125]. The presence of heavy metals in plants can affect other organisms such as bacteria, fungi and herbivores. As reported by Poschenrieder et al. [15], antagonistic, synergistic or no-effect interactions between metal accumulation and infestation of herbivores or infection caused by pathogenic fungi/pathogenic bacteria may occur. In some cases, heavy metal accumulation in plants may function as a self-defence strategy evolved in hyperaccumulator plants against natural enemies [126]. Metal-hyperaccumulating plants are able to accumulate exceptionally high concentrations of metals in their tissues. A new insight was provided that some metal hyperaccumulating plants can use high concentrations of accumulated metals to defend themselves against attacks by pathogenic microorganisms and herbivores [125]. Already, in the introduction of this review work, we mentioned hypotheses concerning heavy metal-plant-pathogen and heavy metal-plant-insect relationships. The first "Elemental defence" hypothesis presented by Poschenrieder et al. [14] assumes that high metal concentrations in plant tissues are deterrent for herbivores or fungi or can kill these organisms [113]. This hypothesis is based on two modes of action by which the plant may exhibit the "elemental defence" against attacking herbivores: (1) the direct toxicity of the consumed plant material on the attacking herbivore $[123,127]$ and (2) the deterrence of herbivores, whereby plant tissues containing elevated concentrations of elements are less preferred by herbivores than plant material not having such high metal concentrations [113,128,129]. Testing this hypothesis, some studies confirmed the role of the accumulation of Ni [127], Cd [130], Zn [131], As [132] and Se [133] and so forth in plant defence mechanisms. Heavy metals can act against herbivores through their toxic action but this does not safeguard the plant from undergoing damages before poisoning the enemy.

The initial mechanisms enabling insects to avoid heavy metal effects might be "avoidance" [134], which leads them to selectively eat only low-metal tissues of the plant and "dietary dilution," consisting in lowering overall metal ingestion by eating both high-metal and low-metal containing tissues [129]. On the other hand, experimental evidence does exist that some herbivores prefer to eat low- $\mathrm{Zn}$ containing Thlaspi caerulescens [110] and low-Ni Senecio coronatus [134] when offered a choice between plants containing either low or high-metal concentrations. Deterrent effects have also been observed for Cd [130], As [132] and Se [133]. This ability to avoid feeding on plants with high levels of heavy metals might support that herbivores have a "taste for metals." Another mechanism deserving a particular interest is "tolerance," in which physiological adaptations allow specialist herbivores to withstand a 
high-metal diet, thus disarming the elemental defences of the plant [135]. The bug Melanotrichus boydi, for instance, prefers to feed on the Ni hyperaccumulator Streptanthus polygaloides [136] and a strain of the moth Plutella xylostella (Lepidoptera: Plutellidae) feeds on the Se hyperaccumulator S. pinnata without suffering from the high-Se diet [123]. However, since the metal treatment will strongly affect the plants' metabolome, it might be that herbivores do not directly perceive metals in their food but rather metal-induced metabolites.

The next hypothesis known as "the joint effects," assumes that many chemicals in plant cell compartments can act separately and/or in combination. If two or more defensive chemicals are enhanced and present combined effects, they display "joint effects" in a defensive model of plant [137]. In general, there are several types of joint effects: additive, synergism and antagonism. The joint effect is considered as additive when two chemicals have a joint effect equal to that of their single effects when combined. The two chemicals display a positive interaction when they have an effect greater than the expected additive effect; the joint effect is thus synergistic. On the contrary, the joint effect is antagonistic if the two chemicals together have an effect lesser than the expected additive effect. "The joint effects" hypothesis has been tested using Spodoptera exigua neonates fed with artificial diets [137]. Metal+metal experiments utilized diets amended with metal pairs, using four metals (Co, $\mathrm{Cu}, \mathrm{Ni}$ and $\mathrm{Zn}$ ) commonly hyperaccumulated by plants. Metals combined with other metals or organic compounds may be more effective against herbivores than individual metals. The latter authors evaluated the type of joint effects between $\mathrm{Co}, \mathrm{Cu}, \mathrm{Ni}$ and $\mathrm{Zn}$ when fed in combinations of two metals to larvae of a model herbivore, S. exigua (Lepidoptera: Noctuidae). Boyd and Moar [138] reported that tissues of the Ni hyperaccumulator $S$. polygaloides was toxic to $S$. exigua when plants hyperaccumulated Ni. Cheruiyot et al. [139] used artificial diets to determine lethal and sub lethal concentrations of four metals ( $\mathrm{Co}, \mathrm{Cu}, \mathrm{Ni}$ and $\mathrm{Zn}$ ) to S. exigua. Another experiment explored the toxicity of four metals hyperaccumulated by plants ( $\mathrm{Cd}, \mathrm{Ni}, \mathrm{Pb}$ and $\mathrm{Zn}$ ) and searched if metal combinations might broaden the defensive effectiveness of metals in S. polygaloides [127]. Metals were used alone and in various combinations such as metal + metal $(\mathrm{Zn}$ plus $\mathrm{Ni}, \mathrm{Pb}$, or $\mathrm{Cd})$. Artificial diet amended with these treatments was fed to larvae of the crucifer specialist herbivore Plutella xylostella. Combinations of metals significantly decreased survival and pupation rates. Effects of combinations were additive rather than synergistic or antagonistic. Because Zn enhanced the toxicity of other metals and Ni enhanced the toxicity of organic defensive chemicals, the defensive effects of metals are more widespread among plants than previously believed.

"The joint effects" hypothesis may justify the simultaneous presence of elemental and organic defences, which may act in concert with each other and enhance the overall plant defences [129]. The results of studies from experiments on inorganic defences and organic defence chemicals in the $\mathrm{Ni}$ hyperaccumulator S. polygaloides and fed to larvae of $P$. xylostella revealed additive joint effects between $\mathrm{Ni}$ and some organic defence chemicals such as atropine, nicotine and tannic acid [127] (Table 1). Combinations of metals plus organic chemicals significantly decreased survival and pupation rates. In turn, the research results of Noret et al. [140] demonstrated that Zn hyperaccumulation in Thlaspi caerulescens did not protect plants against snails, Helix aspersa (Eupulmonata: Helicidae) and raised the important role of secondary metabolites such as glucosinolates in these plants. Therefore, the above results did not support the defence hypothesis of plants by heavy metals and have shown that nonmetallicolous plants afforded a better protection than metallicolous plants, as glucosinolates increased in plants without Zn after herbivore infestation. Winter et al. [141] discovered that copper $(\mathrm{Cu})$ enhanced the capacity of Zea mays to synthesize volatile organic compounds under insect attack. The higher $\mathrm{Cu}$ dose was found to be primed for enhanced volatile production that can be triggered by caterpillar feeding. $\mathrm{Cu}$ stress correlated with increased levels of ROS in roots and priming of herbivore-induced JA in leaves. In turn, Tolrà et al. [114] demonstrated opposing response of T. caerulescens organs after exposure to increasing concentrations of $\mathrm{Zn}$. In leaves of shoots that had accumulated extremely high Zn concentrations, total glucosinolate levels decreased, while in roots the level of glucosinolates increased with increasing $\mathrm{Zn}$ in tissues. This mechanism may 
contribute to increased defence of roots against biotic stressors. In the case of T. caerulescens shoot response, the above-mentioned research results support the hypothesis of a trade-off between $\mathrm{Zn}$ and glucosinolates.

In turn, "the defensive enhancement" hypothesis suggested that, in some plant species, heavy metals can protect the plants against herbivores and pathogens [137]. Following this hypothesis, the threshold protective benefit concentration is crucial, as each concentration can cause death and/or reduced herbivore growth rate, smaller herbivore size at maturity and reduced fecundity. The increased concentrations of inorganic compounds in herbivore bodies may negatively impact their natural enemies, providing a beneficial component to the herbivore. It has been shown that hyperaccumulation and accumulation of certain elements may affect the defence of plants against herbivores. In the context of this hypothesis, it has been demonstrated that As, $\mathrm{Cd}, \mathrm{Ni}$, Se and $\mathrm{Zn}$ repelled the herbivores. The research dedicated to providing evidence of the "joint effects hypothesis" has demonstrated defence at relatively low element concentrations and tests of metal/metal and metal/organic compound combinations have revealed joint effects [129]. On the other hand, sub lethal effects of elements may result in more damage to a plant under some scenarios [142]. Heavy metals absorbed by insects have a clear effect on their growth, mortality and physiology [143]. Zn and Cu connect to the cytosol metallothionein in the midgut of many organisms and, as such, are essential elements but at high concentrations they can be toxic [144]. Cd is highly toxic, even at a low concentration and can create mutations in the organism [145]. The effect of heavy metals on an index such as relative growth rate (RGR) is quite various. For example, the effect of a high concentration of $\mathrm{Ni}$ in Spodoptera litura reduced relative consumption rate (RCR) but a low concentration of Ni increased RGR [146]. A similar study by Baghban et al. [143] on the effect of $\mathrm{Cd}, \mathrm{Cu}$ and $\mathrm{Zn}$ on feeding indices and energy reserves of the cotton boll worm Helicoverpa armigera showed that high concentrations of $\mathrm{Cd}$ significantly increased approximate digestibility. RGR was significantly enhanced with treatments by $\mathrm{Cu}, \mathrm{Cd}$ and $\mathrm{Zn}$. It is clear from the present results that the presence of heavy metals in the environment has an intense impact on insects as far as food consumption. 
Table 1. Effects of heavy metals on the metabolic status of plants and cross talk of heavy metals and biotic stressors.

\begin{tabular}{|c|c|c|c|c|c|c|}
\hline Metal & Concentration & Fungus/Insect & Plant & Increase of Parameter in Plant & Decrease of Parameter in Plant & References \\
\hline $\mathrm{Al}$ & $50 \mu \mathrm{M} \mathrm{AlCl}{ }_{3}$ & Fusarium incarnatum-equiset & Cajanus cajan L. & catalase (CAT), glutathione peroxidase (GPX) & $\begin{array}{c}\mathrm{H}_{2} \mathrm{O}_{2} \text {, superoxide anion, cell } \\
\text { death, superoxide dismutase } \\
\text { (SOD), ascorbate peroxidase (APX) }\end{array}$ & [147] \\
\hline $\mathrm{Al}$ & $250 \mu \mathrm{M} \mathrm{AlCl} l_{3}$ & $\begin{array}{l}\text { Phytophthora infestans } \\
\text { (Mont.) }\end{array}$ & Solanum tuberosum $\mathrm{L}$. & $\begin{array}{l}\text { gene expression of: pathogenesis-related (PR) protein } \\
\text { 1, PR-2, PR-3, phenylalanine ammonia lyase (PAL), } \\
\beta-1,3 \text { glucanase activity, chitinase activity, } \mathrm{H}_{2} \mathrm{O}_{2} \\
\text { salicylic acid (SA), Salicylic acid beta-glucoside (SAG), } \\
\text { S-Nitrosothiols (SNOs), fluorescence intensity of nitric } \\
\text { oxide (FLNO) -in leaves }\end{array}$ & SA, SAG, SNOs, FLNO-in roots & [106] \\
\hline $\mathrm{Cd}$ & $50 \mathrm{CdCl}_{2}$ & Fusarium oxysporum & Triticum aestivum & $\begin{array}{l}\mathrm{Cd}^{2+} \text {-stress associated protein, free protein thiol } \\
\text { content, total protein thiols, glutaredoxin (Grx) acivity }\end{array}$ & $\begin{array}{l}\text { hydrogen peroxide, carbonyl, } \\
\text { cysteine content, glutathione } \\
\text { (GSH), thiol disulfides, }\end{array}$ & {$[148,149]$} \\
\hline $\mathrm{Cd}$ & $1,10 \mu \mathrm{M} \mathrm{CdCl}_{2}$ & Botrytis cinerea & Arabidopsis thaliana & plant defensin (PDF) 1.2 expression & none & [150] \\
\hline $\mathrm{Cd}$ & $\begin{array}{l}250,500,750 \\
1000 \mathrm{mg} \mathrm{Cd} \mathrm{kg}^{-1}\end{array}$ & Frankliniella occidentalis & Thlaspi caerulescens & none & $\begin{array}{c}\text { leaf feeding damage index (LFDI), } \\
\text { number of thrips (Frankliniella } \\
\text { occidentalis) per plant }\end{array}$ & [130] \\
\hline $\mathrm{Cu}$ & $50 \mu \mathrm{M} \mathrm{CuSO}_{4}$ & Verticillium dahliae Kleb. & Capsicum aпnиит $\mathrm{L}$. & $\begin{array}{c}\text { proline oxidase (POX), phenolic compound } \\
\text { peroxidase gene (CAPO1), a sesquiterpene cyclase } \\
\text { gene (CASC1), a PR1 gene (CABPR1) and a } \\
\beta-1,3 \text {-glucanase (CABGLU) }\end{array}$ & chitinase activity & [107] \\
\hline Mn & $\begin{array}{l}350.0 \mathrm{mg} \cdot \mathrm{kg}^{-1} \\
\mathrm{MnSO}_{4} \cdot \mathrm{H}_{2} \mathrm{O}\end{array}$ & $\begin{array}{l}\text { Uncinula necator (Schw.) } \\
\text { Burr }\end{array}$ & Vitis vinifera & $\begin{array}{c}\text { salicylic acid, abscisic acid (ABA), peroxidase (POD), } \\
\text { phenylalanine ammonia lyase (PAL), } \\
\text { pathogenesis-related (PR-like) protein, a nucleotide } \\
\text { binding site-leucine-rich repeat (NBS-LRR) analogue } \\
\text { and a Josephin-like (JOSL) protein }\end{array}$ & $\begin{array}{l}\text { malondialdehyde (MDA), } \\
\text { polyphenol oxidase (PPO), } \\
\text { SOD, CAT }\end{array}$ & [151] \\
\hline $\mathrm{Ni}$ & $\begin{array}{c}20,1500 \mathrm{mg} \cdot \mathrm{kg}^{-1} \\
\mathrm{NiCl}_{2}\end{array}$ & Spodoptera exigua & $\begin{array}{l}\text { Streptanthus } \\
\text { polygaloides }\end{array}$ & larval death & none & [138] \\
\hline $\mathrm{Ni}$ & 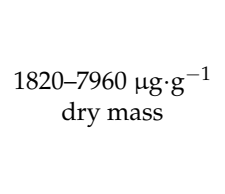 & $\begin{array}{l}\text { Melanoplus femurrubrum, } \\
\text { Evergestis rimosalis, Delia } \\
\text { radicum, Philaenus spumarius, } \\
\text { Lipaphis erysimi, Trialeurodes } \\
\text { vaporariorum, Lygus lineolaris, } \\
\text { Tetranychus urticae }\end{array}$ & $\begin{array}{l}\text { Streptanthus } \\
\text { polygaloides }\end{array}$ & none & survival & [127] \\
\hline
\end{tabular}


Table 1. Cont.

\begin{tabular}{|c|c|c|c|c|c|c|}
\hline Metal & Concentration & Fungus/Insect & Plant & Increase of Parameter in Plant & Decrease of Parameter in Plant & References \\
\hline $\mathrm{Ni}$ & $200 \mu \mathrm{M} \mathrm{Ni}\left(\mathrm{NO}_{3}\right)_{2}$ & Erysiphe cruciferarum & Thlaspi goesingense & $\begin{array}{l}\text { SA metabolites phenylalanine, cinnamic acid, } \\
\text { salicylyl-glucose and catechol }\end{array}$ & none & [123] \\
\hline $\mathrm{Ni}$ & $\begin{array}{c}25,50,75 \text { or } \\
100 \mathrm{mg} \cdot \mathrm{mL}^{-1} \mathrm{Ni}\end{array}$ & $\begin{array}{l}\text { Pythium mamillatum and } P . \\
\text { ultimum }\end{array}$ & $\begin{array}{c}\text { Alyssum serpyllifolium } \\
\text { ssp. lusitanicum and } \\
\text { A. murale }\end{array}$ & none & none & [152] \\
\hline Se & $\begin{array}{l}20 \mu \mathrm{M} \text { sodium } \\
\text { selenate }\end{array}$ & $\begin{array}{l}\text { Pieris rapae, Alternaria, } \\
\text { Brassicicola, Fusarium sp. }\end{array}$ & Brassica juncea & none & feeding rate & [153] \\
\hline Se & $\begin{array}{c}10,20,40 \mu \mathrm{M} \\
\text { sodium selenate }\end{array}$ & Myzus persicae & Brassica juncea & none & aphids per plant & [154] \\
\hline $\mathrm{Zn}$ & $\begin{array}{l}0.5-5 \mathrm{mg} \cdot \mathrm{g}^{-1} \\
\mathrm{ZnSO}_{4}\end{array}$ & Schistocerca gregaria (Forskål) & $\begin{array}{l}\text { Thlaspi caerulescens J. } \\
\text { \& C. }\end{array}$ & none & $\begin{array}{l}\text { time feeding, growth rate, } \\
\text { amount eaten }\end{array}$ & [131] \\
\hline $\mathrm{Zn}$ & $\begin{array}{c}10 \mathrm{mg} \cdot \mathrm{L}^{-1} \\
\mathrm{ZnSO}_{4} \cdot 7 \mathrm{H}_{2} \mathrm{O}\end{array}$ & $\begin{array}{c}\text { Schistocerca gregaria, } \\
\text { Deroceras caruanae, } \\
\text { brassicris }\end{array}$ & $\begin{array}{l}\text { Thlaspi caerulescens } \mathrm{J} \text {. } \\
\text { \& C. }\end{array}$ & none & preferences & [110] \\
\hline
\end{tabular}




\section{Effects of Heavy Metals on Insects Including Aphids}

Insects play a definite role in the trophic chain and, as food for other organisms, they may constitute an important path for the bioaccumulation of heavy metals. Invertebrates, including insects are good models to study toxicity of heavy metals and, as such, are important bioindicators of environmental contaminations [155]. In the published literature, there were several studies related to the transfer of heavy metals between soil-plant-insect [156]. For example, it has been revealed that the concentration of $\mathrm{Cd}$ and $\mathrm{Pb}$ declined with increasing trophic levels, while concentrations of $\mathrm{Zn}$ and $\mathrm{Cu}$ slightly increased from plant to insect. Additionally, numerous literature reports show that the bioamplification (biomagnification) of metals in organisms occurs at higher food chain levels [157-160]. The presence of heavy metals in insects and its impact on growth rate [161-163], mortality [164-168] and physiology [169-171] are well-known. Local adaptation of insects to environments contaminated with heavy metals was also reported [172-176]. For example, van Ooik and Rantala [177] demonstrated that the polluted strain (genotype) of the autumnal moth Epirrita autumnata displayed a better growth on polluted leaves than the non-polluted strain. Besides, it has previously been found that adding heavy metals to food at moderate levels enhanced the immune system of mots, while a high level of heavy metals decreased their immunity [163]. Moreover, herbivore polyphagic species can avoid heavy metals-containing food [131].

On the other hand, it is known that elements such as $\mathrm{Cd}$ are highly toxic, even at a low concentration and have a broad impact on insects causing mutations [145]. Besides, there are some examples of $[178,179]$ harmful effects of this metal on insects. In fact, Kafel et al. [180] demonstrated that the insect Spodoptera exigua had a significantly lower survival rate and body weight upon Cd exposure. In turn, the development of Lymantria dispar L. larvae in the fourth, fifth and sixth instar was delayed and the larval mass in the third and fourth instar decreased [181]. Additionally, Wu et al. [182] showed that Boettcherisca peregrina larvae had altered total larval duration. Moreover, $\mathrm{Cd}$ can also have an impact on antioxidant systems in insects [183]. As reported by Zhang et al. [159], some herbivorous insects are strong accumulators of $\mathrm{Cd}$, for example, Locusta migratoria, Oxya chinensis, Acrida chinensis (Orthoptera), Eligma narcissus or Lymantria dispar (Lepidoptera). As well, $\mathrm{Pb}$ ions can affect cells responsible for insect metamorphosis, damage mitochondrial cristae, decrease ATP synthesis and decrease the production of growth hormones [184]. As a result of the influence of $\mathrm{Pb}$, nanism and malformation of the fly imagines Calliphora vicina, reduces motor activity, delays the formation and the emergence of puparia [185], reduces the fertility and egg hatching in Drosophila melanogaster [186] as well as elongation and finally changes the shape of wings, affect the prolongation and foldation of legs in Musca domestica L. [187]. Moreover, there are some research results showing the deleterious effect of $\mathrm{Hg}$ on the number of developed oocytes, spermatogonia and spermatocytes in Culex pipiens and that $\mathrm{Hg}$ causes abnormality of mosquito's fat body [188]. Also, $\mathrm{Hg}$ ions induce oxidative stress in insect species housefly (Musca domestica), the cabbage looper moth (Trichoplusia ni) [189], two caddisflies (Chimarra sp. and Hydropsyche betteni) and two mayflies (Maccaffertium modestum and Isonychia sp.) [190]. Harmful effects on insects have also been identified for other metals such as Mn [178,179], Cr [144], $\mathrm{Cu}[143,164,191], \mathrm{Hg}[164], \mathrm{Zn}[143,191,192]$ and Ni [191]. Hormesis effects of metals on insects are presented in Table 2. It should also be mentioned that the hormesis effect on insects is mostly observed in response to different insecticides [87,193-203].

Plant contamination with heavy metals may directly affect aphids, due to phloem feeding style and relationships with the plant host [204]. Our latest research has revealed the effect of $\mathrm{Pb}$ on demographic parameters of pea aphid population, that is, pre-reproductive, reproductive and post-reproductive periods, fecundity and longevity and the feeding process by electronic recording of feeding by the Electrical Penetration Graph technique (EPG) (unpublished data). Moreover, it was shown that contamination with $\mathrm{Cu}, \mathrm{Pb}$ [205], $\mathrm{Zn}$ and Cd [206] in host plants like cabbage (Brassica oleracea) and radish (Raphanus sativus) affects the developmental instability of the cabbage aphids Brevicoryne brassicae. The population of cabbage aphids reared on host plants that accumulated heavy metals showed higher fluctuating asymmetry than population reared on non-contaminated ones. Besides, 
$\mathrm{Cd}$ and $\mathrm{Pb}$ effects on morphology of cabbage aphids of both host plants, that is, cabbage and radish, were revealed. All the six measured morphological characters were longer among populations reared on non-contaminated hosts than on contaminated populations, that is, length of ultimate rostral segment, second hind tarsal segment, siphunculi, hind tibia segment, total antennal segment, body length [205]. Moreover, the research of Maryański et al. [207] proved that heavy metal accumulation in aphids might cause additional energy expenditure because of metal detoxification and this might be reflected in an alteration of some traits, such as decreased body mass. These authors showed negative effects of both $\mathrm{Cd}$ and $\mathrm{Zn}$ on sizes of a number of body parts of carabid beetles, Poecillus cupreus L. Moreover, it has been demonstrated that pea aphids are unaffected by Ni accumulation in their host plants such as Streptanthus polygaloides. In turn, the aphid Brachycaudus lychindis L. feeding on $\mathrm{Zn}$ accumulating plants Silene vulgaris, can tolerate elevated levels of heavy metals but such an accumulation in turn changes its morphology [208]. The development time of aphids is relatively shorter than for other groups of insects and depends on the host plant.

Contaminated plants with $\mathrm{Cd}$ and $\mathrm{Pb}$ separately, have important effects on the life history of aphids. The population characteristics of aphids such as fecundity (number of offspring produced per day) and fitness (intrinsic rate of population increase) were lower on contaminated host plants. However, there was no significant effect on development time (from birth to beginning of the first reproduction). Aphid population reared on the contaminated host plants had significantly decreased reproduction potential and their mortality was about $20 \%$ higher on contaminated host plants [209]. Culliney and Pimentel [210] revealed that the green peach aphid Myzus persicae fed on collard plants (Brassica oleracea L.) growing in pots with soils treated with chemically contaminated sewage sludge, had decreased survival and fecundity rates. In turn, Jaworska and Gospodarek [211] performed experiments with plants that were cultivated in soils contaminated with heavy metals such as $\mathrm{Cd}$, $\mathrm{Ni}, \mathrm{Cu}, \mathrm{Zn}$ and $\mathrm{Pb}$ and in soils with natural contents of these elements. It was demonstrated that in both experimental years, aphids preyed more numerously on plants cultivated in the contaminated soil [211]. Besides, Mg fertilization of heavy metal-contaminated soils caused lower $\mathrm{Cd}$ and $\mathrm{Ni}$ contents and lower the number of Aphis fabae [212]. Not all experiments about effects of host plant contaminated with heavy metals on the life history traits are clear and it may depend on many factors. Feeding aphids on contaminated host plants can cause accumulation of harmful metals in their body tissues and affect introduction into food chains [156]. In addition, aphid infestation led to enhanced concentrations of heavy metals in the phloem sap [213]. Studies about the effects of heavy metalcontaminated plants on aphids are limited. Earlier studies also revealed that aphids from contaminated host plants with $\mathrm{Cu}$, firstly excreted $\mathrm{Cu}$ with honeydew although its concentration in body tissues did not increase [214]. It has been noted that high metal concentrations had small adverse, not repeatable effects on development, reproduction and growth of aphids. Experiments were planned where green peach aphids (Myzus persicae L.) could choose plant Brassica juncea contaminated with or without Se. M. persicae clearly avoids plants containing Se. In another nonchoice experiment, accumulation of Se decreased up to 50\% the growth of aphids and was even lethal. Hanson [154] reported that Se-hyperaccumulators can protect plants from aphid feeding two orders of magnitude higher than the non-hyperaccumulators. Moreover, Boyd and Martens [215] noticed that the concentration of Ni in aphids feeding on high-Ni plants (hyperaccumulating plants) was not dramatically increased. It was found that a high level of $\mathrm{Ni}$ in Ni-hyperaccumulator plants did not protect plants against aphids. On the basis of the analysed literature, it can thus be concluded that the influence of metals on aphids is diverse and dependent on heavy metals, plant species and predisposition of the plant for metal accumulation. Therefore, there is the need for further research in this area. 
Table 2. Effects of heavy metals at hormetic and toxic doses on invertebrates.

\begin{tabular}{|c|c|c|c|c|c|c|}
\hline Metal & Concentration & Invertebrata & $\begin{array}{l}\text { Hormetic/Toxic } \\
\text { Effect }\end{array}$ & $\begin{array}{l}\text { Increase of Parameter in } \\
\text { Invertebrata }\end{array}$ & $\begin{array}{l}\text { Decrease of Parameter in } \\
\text { Invertebrata }\end{array}$ & References \\
\hline \multirow{2}{*}{$\mathrm{Cd}$} & $\begin{array}{c}0.0002,0.00022,0.0004,0.0022,0.0202 \\
0.2002 \mathrm{ppm} \mathrm{CdCl}\end{array}$ & \multirow{2}{*}{$\begin{array}{l}\text { Phormia regina Meig. } \\
\text { (Class: Insecta) }\end{array}$} & hormetic effect & $\begin{array}{l}\text { mean percent pupation, stage } \\
\text { specific death }\end{array}$ & mean $\%$ emergence, pupae death & \multirow{2}{*}{ [81] } \\
\hline & $2.0002,20.0002,200.0002 \mathrm{ppm} \mathrm{CdCl}_{2}$ & & toxic effect & pupae death, stage specific death & $\begin{array}{c}\text { mean } \% \text { pupation, mean } \% \\
\text { emergence, }\end{array}$ & \\
\hline \multirow[t]{2}{*}{$\mathrm{Cd}$} & $10.53,7.01,5.84,5.25, \mathrm{ng} \cdot \mathrm{cm}^{-2} \mathrm{Cd}^{2+}$ & \multirow{2}{*}{$\begin{array}{c}\text { Eisenia fetida } \\
\text { (Class: Clitellata) }\end{array}$} & hormetic effect & $\begin{array}{c}\text { catalase (CAT), } \\
\text { sodium dismutase (SOD) }\end{array}$ & none & \multirow[t]{2}{*}{ [159] } \\
\hline & $0.33,0.66$ and $1.32 \mathrm{ng} \cdot \mathrm{m}^{-2} \mathrm{Cd}^{2+}$ & & toxic effect & none & CAT, SOD & \\
\hline $\mathrm{Cu}$ & $\begin{array}{c}0.04 \mathrm{mM}, 0.16 \mathrm{mM}, 0.63 \mathrm{mM}, 2.5 \mathrm{mM} \\
10 \mathrm{mM}, 40 \mathrm{mM} \text { and } 160 \mathrm{mM} \\
\mathrm{Cu}\left(\mathrm{NO}_{3}\right)_{2} \cdot 3 \mathrm{H}_{2} \mathrm{O}\end{array}$ & $\begin{array}{l}\text { Folsomia candida } \\
\text { (Class: Entognatha) }\end{array}$ & hormetic effect & survival & none & [82] \\
\hline $\mathrm{MeHg}$ & $0,2 \mathrm{mM}, 0,4 \mathrm{mM} \mathrm{MeHgCl}$ & $\begin{array}{l}\text { Caenorhabditis elegans } \\
\text { (Class: Chromadorea) }\end{array}$ & hormetic effect & $\begin{array}{l}\text { expression of glutathione } \\
\text { S-transferases (gst-4): GFP } \\
\text { (green fluorescence protein) }\end{array}$ & $\begin{array}{l}\text { heat shock proteins (hsp-4):GFP, } \\
\text { metallothioneins (mtl-1):GFP } \\
\text { and mtl-2:GFP }\end{array}$ & [84] \\
\hline \multirow{2}{*}{$\mathrm{Ni}$} & $\begin{array}{c}50 \text { and } 100 \mathrm{mg} \cdot \mathrm{kg}^{-1}\left[\mathrm{Ni}\left(\mathrm{NO}_{3}\right)_{2}\right. \\
\left.6 \mathrm{H}_{3} \mathrm{O}\right]\end{array}$ & \multirow{2}{*}{$\begin{array}{l}\text { Eisenia fetida } \\
\text { (Class: Clitellata) }\end{array}$} & hormetic effect & $\begin{array}{l}\text { microbial biomass carbon, soil } \\
\text { basal respiration }\end{array}$ & dehydrogenase activities & \multirow{2}{*}{ [86] } \\
\hline & 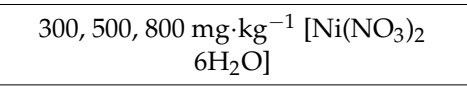 & & toxic effect & none & $\begin{array}{l}\text { urease (UA) and dehydrogenase } \\
\text { activities }\end{array}$ & \\
\hline \multirow{2}{*}{$\mathrm{U}$} & $\begin{array}{c}1.86,5.0,9.3 \mathrm{mg} \cdot \mathrm{kg}^{-1} \text { depleted } \\
\text { uranium (DU) }\end{array}$ & \multirow{2}{*}{$\begin{array}{l}\text { Eisenia fetida } \\
\text { (Class: Clitellata) }\end{array}$} & hormetic effect & $\begin{array}{l}\text { natural red retention time, DNA } \\
\text { breaks }\end{array}$ & toxicity factor & \multirow{2}{*}{ [83] } \\
\hline & $\begin{array}{c}18.6,50,93,150,186,300 \text { and } \\
600 \mathrm{mg} \cdot \mathrm{kg}^{-1} \mathrm{DU}\end{array}$ & & toxic effect & DNA breaks & toxicity factor & \\
\hline
\end{tabular}




\section{Effects of Heavy Metals on Fungi}

Stimulation of fungal growth by low levels of heavy metals has generally been scarcely reported. In the published literature, there are reports concerning the stimulating effect of heavy metals on the growth of mycelium of pathogenic fungi as well as edible fungi (Table 3). For example, metal ion treatments with $5 \mathrm{mg} \cdot \mathrm{L}^{-1}$ of $\mathrm{Zn}, \mathrm{Cu}^{2+}$ and $\mathrm{Fe}^{2+}$ independently had a stimulating effect on the mycelial growth of Aspergillus flavus [216]. In turn, salts of $\mathrm{Cu}^{2+}, \mathrm{Fe}^{2+}$ and $\mathrm{Fe}^{3+}$ at concentrations such as $5 \times 10^{-4} \mathrm{M}$ and $5 \times 10^{-3} \mathrm{M}$ enhanced mycelial growth of the fungus Endothia parasitica, while at a concentration of $5 \times 10^{-4} \mathrm{M}, \mathrm{Zn}$ only induced a slight stimulation of the growth of the mycelium [217]. Moreover, the stimulating impact of $\mathrm{Pb}$, at a concentration of $3 \mathrm{ppm}$, on the mycelial growth of Pythium debaryanum (R. Hesse) was observed [218]. Additionally, stimulation of the mycelial growth as a result of the impact of heavy metals such as $\mathrm{Zn}$ at concentrations $100-400 \mathrm{mg} \cdot \mathrm{kg}^{-1}$ on Coniothyrum sp. [219], Cr at 20-100 mg.kg ${ }^{-1}, \mathrm{Li}$ at $20-100 \mathrm{mg} \cdot \mathrm{kg}^{-1}$ and $\mathrm{Mn}$ at $10-400 \mathrm{mg} \cdot \mathrm{kg}^{-1}$ on Agrocybe praecox [220] and $\mathrm{Cu}$ at $40 \mathrm{ppm}$ and $\mathrm{Pb}$ on Cryptococcus neoformans [221] was observed.

Binsadiq and Al-Rahmah [222] demonstrated tolerance mechanisms of fungi in the presence of heavy metals. There are two suggested mechanisms for heavy metal tolerance in fungi, that is, extracellular sequestration (which includes chelation and cell-wall binding) and intracellular sequestration by binding ligands [223]. The influence of heavy metals can exert against microorganisms themselves and through microbial processes [218]. Whipps [224] provided evidence that the influence of heavy metals on the microbial processes in the soil can occur through effects on the decomposition of litter, enzyme activity and growth of plants. In turn, Rudawska et al. [225] showed that heavy metals influence the fungal population by changing the number, the composition and the diversity of microorganisms. The chemical and physical properties of the soil affect the presence of fungi in the soil [226] and these soil characteristics may change according to increased concentrations of heavy metals which can be present separately [227] or in combination [228]. It should be stressed that the interaction between heavy metals and pathogenic fungi is dependent on many factors, that is, the degree of tolerance of the fungi and their possibility of absorption of the heavy metals. However, Agrios [229] indicated that, as a result of adverse environmental factors, different types of fungi became able to survive in the forms of scleroses, chlamydospores, or others. Van West et al. [230] suggested that some fungal species display tolerance to the presence of heavy metals in the environment. In turn, Khan et al. [19] reported that fungi can be used as bioremediators in the polluted soils or as bioindicators.

On the other hand, the toxic effects of heavy metals on mycelial growth are mostly described in the literature. Stroiński and Floryszak-Wieczorek $[231,232]$ demonstrated that the cell membrane is the first target of the toxic action of metals which can cause electrolyte leakage and modification of the membrane permeability. Besides, heavy metals induce the generation of ROS upon fungal oxidative stress [233]. It must be emphasized that the toxic effects of heavy metals on fungal growth vary widely, depending on the type of metals, their concentration and the considered fungal species [234]. Hartikainen et al. $[219,220]$ studied the effects of $\mathrm{Zn}, \mathrm{Cu}, \mathrm{Cd}, \mathrm{Co}, \mathrm{Cr}$ and $\mathrm{Li}$ on many fungal species belonging to taxons such as Ascomycota, Basidiomycota and Zygomycota. These authors demonstrated harmful effects of these heavy metals on mycelium growth. In addition, $\mathrm{Ag}, \mathrm{Co}, \mathrm{Cu}, \mathrm{Fe}, \mathrm{Hg}, \mathrm{Mn}$, $\mathrm{Pb}$ and $\mathrm{Zn}$ had a deleterious impact on fungi of Nematophagus including Trichoderma harzianum, Trichoderma virens, Trichoderma hamatum, Pochonia chlamydosporia var. chlamydosporia and Arthrobotrys oligospora [235]. Moreover, Abu-Mejdad [221] demonstrated that the ionic forms of $\mathrm{Cu}$ and $\mathrm{Zn}$ inhibited the mycelial growth of Aspergilus niger, Candida albicans and Cryptococcus neoformans. In the presence of $\mathrm{Cu}, \mathrm{Zn}, \mathrm{Cd}$ and $\mathrm{Pb}$, the mycelial growth speed of the fungi Fusarium oxysporum Schlecht. and Pythium debaryanum (R. Hesse) was considerably inhibited [218].

On the other hand, there are also reports in the published literature showing that the edible fungus Imleria badia is capable of accumulating high concentrations of various elements, including toxic metals and metalloids and this fact consequently had a significant effect on the total content of phenolic compounds and the antioxidant potential [236]. 
Metals can also enhance the resistance of plants to fungal infection. Triticum aestivum var Sonalika seedlings pre-exposed to $50 \mu \mathrm{M} \mathrm{CdCl}_{2}$ during $48 \mathrm{~h}$ and infected with Fusarium oxysporum did not exhibit Fusarium wilt, while the untreated seedlings displayed disease symptoms characteristics for Fusarium infection within 7 days post inoculation [148]. Moreover, a similar inhibitory effect of heavy metals such as $\mathrm{Cd}, \mathrm{Al}, \mathrm{Mn}$ and $\mathrm{Cu}$ on the development of infections caused by fungal pathogens are presented in Table 3.

On the other hand, latest research concerning hormesis has focused on the effects of sub lethal doses of metal-containing fungicides on growth and virulence stimulations of plant-pathogenic fungi and oomycetes. There are a lot of reports of hormetic responses in plant pathogens. One of the earliest observations performed by Southam and Ehrlich [237] demonstrated an hormetic response in plant pathogens, for example, stimulation of the metabolism of a wood-decaying fungus Fomitopsis officinalis by red cedar extracts. In turn, Hessayon [238] demonstrated the hormesis effect of trichothecin on Fusarium oxysporum. Similar examples were also noted in the case of Pythium aphanidermatum, which was stimulated by the fungicide mefenoxam [239]. Moreover, the presence of thiabendazole increased the germination of Penicillium expansum [240]. Also, the mycelial growths of fungi such as Lyophyllum palustre (Peck) Singer [241] and Phythium aphanidermatum, P. irregular and P. ultimatum were increased by propamocarb [242]. Besides, Phytophthora infestans growth increased as a result of the impact of metalaxyl [243] and Sclerotinia sclerotiorum under treatment with dimethachlon conditions [244]. 
Table 3. Effects of heavy metals at hormetic and toxic dose on fungi.

\begin{tabular}{|c|c|c|c|c|c|c|}
\hline Metal & Concentration & Plant Species & $\begin{array}{l}\text { Hormetic/Toxic } \\
\text { Effect }\end{array}$ & $\begin{array}{c}\text { Increase of Parameter } \\
\text { in Fungi }\end{array}$ & $\begin{array}{c}\text { Decrease of Parameter } \\
\text { in Fungi }\end{array}$ & References \\
\hline $\mathrm{Cd}$ & $5 \mathrm{mg} \cdot \mathrm{L}^{-1}$ & Aspergillus flavus & hormetic effect & $\begin{array}{c}\text { total RNA, aflatoxin, } \\
\text { O-methylsterigmatocystin }\end{array}$ & none & [216] \\
\hline $\mathrm{Cr}$ & $\begin{array}{c}20-100 \mathrm{mg} \cdot \mathrm{kg}^{-1} \\
\mathrm{KCr}\left(\mathrm{SO}_{4}\right)_{2} \cdot 12 \mathrm{H}_{2} \mathrm{O}\end{array}$ & Agrocybe praecox & hormesis effect & none & Enzyme production & \multirow[b]{2}{*}[220]{} \\
\hline $\mathrm{Cr}$ & $\begin{array}{c}20-100 \mathrm{mg} \cdot \mathrm{kg}^{-1} \mathrm{KCr}\left(\mathrm{SO}_{4}\right)_{2} \\
\cdot 12 \mathrm{H}_{2} \mathrm{O}\end{array}$ & $\begin{array}{l}\text { Pleurotus pulmonarius, Phlebia radiata, } \\
\text { Physisporinus rivulosus and } \\
\text { Stropharia rugosoannulata }\end{array}$ & toxic effect & none & none & \\
\hline $\mathrm{Cu}$ & $5 \mathrm{mg} \cdot \mathrm{L}^{-1}$ & Aspergillus flavus & hormetic effect & $\begin{array}{c}\text { total RNA, aflatoxin, } \\
\text { O-methylsterigmatocystin }\end{array}$ & none & {$[216]$} \\
\hline $\mathrm{Cu}$ & $\begin{array}{c}5 \cdot 10^{-4} \mathrm{M}, 5 \cdot 10^{-3} \mathrm{M} \mathrm{CuSO}_{4} \\
\text { and } \mathrm{CuCl}\end{array}$ & Endothia parasitica & hormetic effect & none & none & [217] \\
\hline $\mathrm{Cu}$ & $3 \mathrm{ppm} \mathrm{CuSO}_{4} \cdot 5 \mathrm{H}_{2} \mathrm{O}$ & Suillus luteus & hormetic effect & none & none & {$[218]$} \\
\hline \multirow{2}{*}{$\mathrm{Cu}$} & $20 \mathrm{ppm}$ & \multirow{2}{*}{ Cryptococcus neoformans } & hormetic effect & & & \multirow{2}{*}{ [221] } \\
\hline & $40 \mathrm{ppm}$ & & toxic effect & & & \\
\hline \multirow{2}{*}{$\mathrm{Fe}$} & $5 \mathrm{mg} \cdot \mathrm{L}^{-1}$ & Aspergillus flavus & hormetic effect & $\begin{array}{c}\text { total RNA, aflatoxin, } \\
\text { O-methylsterigmatocystin }\end{array}$ & none & {$[216]$} \\
\hline & $\begin{array}{c}5 \cdot 10^{-4} \mathrm{M} \text { and } 5 \cdot 10^{-3} \mathrm{M} \\
\mathrm{FeCl}_{2} \cdot 4 \mathrm{H}_{2} \mathrm{O} \cdot \mathrm{FeCl}_{3} \cdot 6 \mathrm{H}_{2} \mathrm{O}\end{array}$ & Endothia parasitica & hormetic effect & none & none & {$[217]$} \\
\hline \multirow[b]{2}{*}{$\mathrm{Li}$} & $20-100 \mathrm{mg} \cdot \mathrm{kg}^{-1} \mathrm{Li}_{2} \mathrm{SO}_{4} \cdot \mathrm{H}_{2} \mathrm{O}$ & Agrocybe praecox & hormetic effect & none & none & \multirow[b]{2}{*}[220]{} \\
\hline & $20-100 \mathrm{mg} \cdot \mathrm{kg}^{-1} \mathrm{Li}_{2} \mathrm{SO}_{4} \cdot \mathrm{H}_{2} \mathrm{O}$ & $\begin{array}{c}\text { Pleurotus pulmonarius, Phlebia radiata, } \\
\text { Physisporinus rivulosus and } \\
\text { Stropharia rugosoannulata }\end{array}$ & toxic effect & none & none & \\
\hline $\mathrm{Pb}$ & $3,33 \mathrm{ppm} \mathrm{Pb}\left(\mathrm{NO}_{3}\right)_{2}$ & Suillus luteus & hormetic effect & none & none & \multirow{2}{*}{ [218] } \\
\hline $\mathrm{Pb}$ & 3 ppm $\mathrm{Pb}\left(\mathrm{NO}_{3}\right)_{2}$ & Hebeloma spp. & hormetic effect & none & none & \\
\hline $\mathrm{Mn}$ & $\begin{array}{c}10-400 \mathrm{mg} \cdot \mathrm{kg}^{-1} \\
\mathrm{MnSO}_{4} \cdot 4 \mathrm{H}_{2} \mathrm{O}\end{array}$ & Agrocybe praecox & hormetic effect & none & none & \multirow[b]{2}{*}[220]{} \\
\hline $\mathrm{Mn}$ & $\begin{array}{l}10-400 \mathrm{mg} \cdot \mathrm{kg}^{-1} \\
\mathrm{MnSO}_{4} \cdot 4 \mathrm{H}_{2} \mathrm{O}\end{array}$ & $\begin{array}{l}\text { Pleurotus pulmonarius, Phlebia radiata, } \\
\text { Physisporinus rivulosus and } \\
\text { Stropharia rugosoannulata }\end{array}$ & toxic effect & none & none & \\
\hline
\end{tabular}


Table 3. Cont.

\begin{tabular}{|c|c|c|c|c|c|c|}
\hline Metal & Concentration & Plant Species & $\begin{array}{c}\text { Hormetic/Toxic } \\
\text { Effect }\end{array}$ & $\begin{array}{l}\text { Increase of Parameter } \\
\text { in Fungi }\end{array}$ & $\begin{array}{l}\text { Decrease of Parameter } \\
\text { in Fungi }\end{array}$ & References \\
\hline $\mathrm{Zn}$ & $5 \cdot 10^{-4} \mathrm{M} \mathrm{ZnSO}_{4} \cdot 7 \mathrm{H}_{2} \mathrm{O}$ & Endothia parasitica & hormetic effect & none & none & [217] \\
\hline $\mathrm{Zn}$ & $3 \mathrm{ppm} \mathrm{ZnSO}_{4} \cdot 7 \mathrm{H}_{2} \mathrm{O}$ & Hebeloma spp. & hormetic effect & none & none & {$[218]$} \\
\hline \multirow{3}{*}{$\mathrm{Zn}$} & $100 \mathrm{mg} \cdot \mathrm{kg}^{-1} \mathrm{Zn}$ & $\begin{array}{c}\text { Agrocybe praecox, Gymnopus peronatus, } \\
\text { Gymnopilus sapineus, Stropharia rugosoannulata, } \\
\text { Mycena galericulata }\end{array}$ & hormetic effect & none & none & \multirow{3}{*}{ [219] } \\
\hline & $100,200,400 \mathrm{mg} \mathrm{Zn} \mathrm{kg}{ }^{-1}$ & $\begin{array}{l}\text { Sordaria sp., Pyrenophora sp., Alternaria sp., } \\
\text { Chaetomium sp., Fusarium sp., Epicoccum sp., } \\
\text { Gliocladium sp., Mortierella sp., } \\
\text { Cylindrocarpon sp. }\end{array}$ & toxic effect & $\begin{array}{l}\text { Enzyme production on } \\
\text { ABTS malt extract } \\
\text { agar plates }\end{array}$ & none & \\
\hline & $100 \mathrm{mg} \cdot \mathrm{kg}^{-1} \mathrm{Zn}$ & $\begin{array}{c}\text { Agaricus bisporus, Gymnopilus luteofolius, } \\
\text { Stropharia aeruginosa }\end{array}$ & toxic effect & none & none & \\
\hline
\end{tabular}




\section{Effects of Heavy Metals Deposition in the Environment on the Formation of Ecological Communities of Aphids under Natural Conditions}

In recent years, increased interest has arisen in environmental research, whose results have underlined the relationship between the impact of environmental factors, including heavy metals and invertebrates, including aphids in natural uncontrolled conditions. Aphids react to all environmental changes and are considered to be organisms that have the ability to adapt to specific ecological conditions [245]. Abiotic factors such as temperature, photoperiod, atmosphere quality, heavy metals have a significant impact on the development of these insects. Czylok et al. [246] revealed aphid communities occurring in metalliferous areas. Baker et al. [247] reported that ecological communities (biocoenosis) formed on soils with high levels of heavy metals have unique flora and fauna. Adverse environmental factors exert a strong selection pressure on organisms and the appearance, during coevolution, of new ecotypes or kinds of plants which are more resistant [248]. According to Osiadacz and Hałaj [249], it would be important to find out whether the pressure exerted on plants could also affect a higher level of the food chain, that is, primary consumers, especially insects. These authors carried out research to clarify which aphid species and how numerous occur in metalliferous areas and whether they can form characteristic aphid communities. The obtained results demonstrated that metalliferous areas have characteristic communities associated with heavy metal grasslands. They concluded that the high content of metals in the soil did not affect the number of aphid species in the aphid communities but help to form species-rich characteristic for these communities. Moreover, Mackoś-Iwaszko [250] performed observations on the species composition and the number of arthropods from various trophic groups settling the hawthorn Crataegus xmedia growing in urban conditions in different degrees of anthropopressure. The formation of proper aphid species in the city plays a crucial role. These works revealed that the sucking-piercing phytophagous aphids were the dominating trophic group settling C. xmedia.

In turn, other studies revealed that in an urban environment with different degrees of pollution (street and a large green complex), aphids were abundant on Acer platanoides [251]. Besides, the number of aphids was significantly higher in the street site than in a large green complex and the highest number of aphids was observed for Periphyllus genus, which are better adapted to urbanized conditions due to high diapausing generations (morphs). The review of Mogren and Trumble [171] evaluated the effects of metal and metalloid pollution on insect behaviors in various environmental conditions. Presented data reveal that a surprising number of insect species cannot detect metal and metalloid contamination, therefore do not always avoid food with significant metal concentrations. The consequence of this was a modification of ingestion, locomotor and reproductive behaviors of insects. Bahadorani and Hilliker and Hanson et al. [154,252] reported that other species of insects moved to contaminated locations, resulting in general reduced species fitness, decrease of population size, species diversity and numerical superiority. In contrast, some species of aquatic insects showed a tendency to escape from contaminated sites [253].

\section{Conclusions}

In the presented review, we have provided data regarding the effect of heavy metals at low doses (the so-called hormetic effect) and toxic doses on the defense responses of plants and the cross-talk of heavy metals and biotic stressors such as insects or pathogenic fungi. Moreover, the hormetic response of insects and pathogens of plants was described. Additionally, we show the relationship between the impact of environmental factors, including heavy metals and invertebrates in natural uncontrolled conditions.

Supplementary Materials: Supplementary materials (Table S1) can be found online. 
Author Contributions: I.M. and A.W., a Ph.D. student of I.M. wrote the manuscript, creating tables, literature analysis and editing; I.M. created the concept and section design (this concept was the basis of a research project for young scientists of A.W. for the Polish National Science Center NCN, registration No. 2017/25/N/NZ9/00704), analyzed literature and wrote the Sections 4 and 5; V.C.M. to participated in creating the Section 3; R.R.-S. participated in creating the concept of the manuscript; P.J. made formal analysis and edited the whole manuscript.

Funding: This work was supported by the National Science Center, Poland, grant number 2017/25/N/NZ9/00704.

Conflicts of Interest: The authors declare no conflict of interests. The funders had no role in the design of the study; in the collection, analyses, or interpretation of data; in the writing of the manuscript and in the decision to publish the results.

\section{References}

1. Straalen, N.; Donker, M. Heavy metals adaptation in terrestial arthropods-Physiological and genetic aspects. Proc. Exp. Appl. Entomol. Neth. Entomol. Soc. 1994, 5, 3-17.

2. Wang, S.; Li, R.; Zhang, Z.; Feng, J.; Shen, F. Assessment of the heavy metal pollution and potential ecological hazardous in agricultural soils and crops of Tongguan, Shaanxi Province. J. Environ. Sci. China 2014, 34, 2313-2320.

3. Yadav, S.K. Heavy metals toxicity in plants: An overview on the role of glutathione and phytochelatins in heavy metal stress tolerance of plants. S. Afr. J. Bot. 2010, 76, 167-179. [CrossRef]

4. Wierzbicka, A.; Bohgard, M.; Pagels, J.H.; Dahl, A.; Löndahl, J.; Hussein, T.; Swietlicki, E.; Gudmundsson, A. Quantification of differences between occupancy and total monitoring periods for better assessment of exposure to particles in indoor environments. Atmos. Environ. 2015, 106, 419-428. [CrossRef]

5. Bell, J.N.B.; Treshow, M. Air Pollution and Plant Life; John Wiley \& Sons: Hoboken, NJ, USA, 2002; ISBN 978-0-471-49091-3.

6. Mleczek, M.; Goliński, P.; Krzesłowska, M.; Gąsecka, M.; Magdziak, Z.; Rutkowski, P.; Budzyńska, S.; Waliszewska, B.; Kozubik, T.; Karolewski, Z.; et al. Phytoextraction of potentially toxic elements by six tree species growing on hazardous mining sludge. Environ. Sci. Pollut. Res. 2017, 24, 22183-22195. [CrossRef] [PubMed]

7. Chmielowska-Bąk, J.; Izbiańska, K.; Ekner-Grzyb, A.; Bayar, M.; Deckert, J. Cadmium stress leads to rapid increase in RNA oxidative modifications in soybean seedlings. Front. Plant Sci. 2018, 8. [CrossRef] [PubMed]

8. Pastor, V.; Luna, E.; Mauch-Mani, B.; Ton, J.; Flors, V. Primed plants do not forget. Environ. Exp. Bot. 2013, 94, 46-56. [CrossRef]

9. Chen, K.; Arora, R. Priming memory invokes seed stress-tolerance. Environ. Exp. Bot. 2013, 94, 33-45. [CrossRef]

10. Borges, A.A.; Jiménez-Arias, D.; Expósito-Rodríguez, M.; Sandalio, L.M.; Pérez, J.A. Priming crops against biotic and abiotic stresses: MSB as a tool for studying mechanisms. Front. Plant Sci. 2014, 5. [CrossRef] [PubMed]

11. Bruce, T.J.A.; Matthes, M.C.; Napier, J.A.; Pickett, J.A. Stressful "memories" of plants: Evidence and possible mechanisms. Plant Sci. 2007, 173, 603-608. [CrossRef]

12. Ahmad, S.; Gordon-Weeks, R.; Pickett, J.; Ton, J. Natural variation in priming of basal resistance: From evolutionary origin to agricultural exploitation: Natural variation in priming of basal resistance. Mol. Plant Pathol. 2010, 11, 817-827. [CrossRef] [PubMed]

13. Fujita, M.; Fujita, Y.; Noutoshi, Y.; Takahashi, F.; Narusaka, Y.; Yamaguchi-Shinozaki, K.; Shinozaki, K. Crosstalk between abiotic and biotic stress responses: A current view from the points of convergence in the stress signaling networks. Curr. Opin. Plant Biol. 2006, 9, 436-442. [CrossRef] [PubMed]

14. Poschenrieder, C.; Tolrà, R.; Barceló, J. Can metals defend plants against biotic stress? Trends Plant Sci. 2006, 11, 288-295. [CrossRef] [PubMed]

15. Poschenrieder, C.; Tolrà, R.; Barceló, J. Interactions between metal ion toxicity and defences against biotic stress: Glucosinolates and benzoxazinoids as case studies. For. Snow Landsc. Res. 2006, 80, 149-160.

16. Holleman, N.; Wiberg, E. Lehrbuch der Anorganischen Chemie; Walter de Gruyter: Berlin, German, 1985.

17. Sebastiani, L.; Scebba, F.; Tognetti, R. Heavy metal accumulation and growth responses in poplar clones Eridano (Populus deltoides $\times$ maximowiczii) and I-214 (P. $\times$ euramericana) exposed to industrial waste. Environ. Exp. Bot. 2004, 52, 79-88. [CrossRef] 
18. Rai, V.; Khatoon, S.; Bisht, S.S.; Mehrotra, S. Effect of cadmium on growth, ultramorphology of leaf and secondary metabolites of Phyllanthus amarus Schum. and Thonn. Chemosphere 2005, 61, 1644-1650. [CrossRef] [PubMed]

19. Khan, A.; Kuek, C.; Chaudhry, T.; Khoo, C.; Hayes, W. Role of plants, mycorrhizae and phytochelators in heavy metal contaminated land remediation. Chemosphere 2000, 41, 197-207. [CrossRef]

20. Clemens, S. Molecular mechanisms of plant metal tolerance and homeostasis. Planta 2001, 212, 475-486. [CrossRef] [PubMed]

21. Chang, C.Y.; Yu, H.Y.; Chen, J.J.; Li, F.B.; Zhang, H.H.; Liu, C.P. Accumulation of heavy metals in leaf vegetables from agricultural soils and associated potential health risks in the Pearl River Delta, South China. Environ. Monit. Assess. 2014, 186, 1547-1560. [CrossRef] [PubMed]

22. Singh, A.; Prasad, S.M. Remediation of heavy metal contaminated ecosystem: An overview on technology advancement. Int. J. Environ. Sci. Technol. 2015, 12, 353-366. [CrossRef]

23. Farouk, S.; Mosa, A.A.; Taha, A.A.; Ibrahim, H.M.; El-Gahmery, A.M. Protective effect of humic acid and chitosan on radish (Raphanus sativus, L. var. sativus) plants subjected to cadmium stress. J. Stress Physiol. Biochem. 2011, 7, 99-116.

24. Swartjes, F.A.; Breemen, E.M.D.; Otte, P.F.; Beelen, P.V.; Rikken, M.G.J.; Tuinstra, J. Human health risks due to consumption of vegetables from contaminated sites. RIVM Rep. 2007, 711701040, 2007.

25. Badawy, S.H.; Helal, M.I.; Chaudri, A.M.; Lawlor, K.; McGrath, S.P. Soli solid-phase controls lead activity in soil solution. J. Environ. Qual. 2002, 31, 162-167. [CrossRef] [PubMed]

26. Zornoza, P.; Vázquez, S.; Esteban, E.; Fernández-Pascual, M.; Carpena, R. Cadmium-stress in nodulated white lupin: Strategies to avoid toxicity. Plant Physiol. Biochem. 2002, 40, 1003-1009. [CrossRef]

27. Tomaszewska, B.; Tukendorf, A.; Barałkiewicz, D. The synthesis of phytochelatins in lupin roots treated with lead ions. Sci. Legumes 1996, 3, 206-217.

28. Małecka, A.; Jarmuszkiewicz, W.; Tomaszewska, B. Antioxidative defense to lead stress in sub cellular compartments of pea root cells. Acta Biochim. Pol. 2001, 48, 687-698. [PubMed]

29. Małecka, A.; Piechalak, A.; Morkunas, I.; Tomaszewska, B. Accumulation of lead in root cells of Pisum sativum. Acta Physiol. Plant. 2008, 30, 629-637. [CrossRef]

30. Rucinska, R.; Gwozdz, E.A. Influence of lead on membrane permeability and lipoxygenase activity in lupine roots. Biol. Plant. 2005, 49, 617-619. [CrossRef]

31. Pawlak-Sprada, S.; Arasimowicz-Jelonek, M.; Podgórska, M.; Deckert, J. Activation of phenylpropanoid pathway in legume plants exposed to heavy metals. Part I. Effects of cadmium and lead on phenylalanine ammonia-lyase gene expression, enzyme activity and lignin content. Acta Biochim. Pol. 2011, 58, 6.

32. Rucińska-Sobkowiak, R. Water relations in plants subjected to heavy metal stresses. Acta Physiol. Plant. 2016, 38. [CrossRef]

33. Krzesłowska, M.; Woźny, A. Lead uptake, localization and changes in cell ultrastructure of Funaria hygrometrica protonemata. Biol. Plant. 1996, 38, 253-259. [CrossRef]

34. Krzesłowska, M.; Lenartowska, M.; Samardakiewicz, S.; Bilski, H.; Woźny, A. Lead deposited in the cell wall of Funaria hygrometrica protonemata is not stable-A remobilization can occur. Environ. Pollut. 2010, 158, 325-338. [CrossRef] [PubMed]

35. Woźniak, A.; Drzewiecka, K.; Kęsy, J.; Marczak, Ł.; Narożna, D.; Grobela, M.; Motała, R.; Bocianowski, J.; Morkunas, I. The influence of lead on generation of signalling molecules and accumulation of flavonoids in pea seedlings in response to pea aphid infestation. Molecules 2017, 22, 1404. [CrossRef] [PubMed]

36. Drzewiecka, K.; Gasecka, M.; Rutkowski, P.; Magdziak, Z.; Goliński, P.; Mleczek, M. Arsenic forms and their combinations induce differences in phenolic accumulation in Ulmus laevis Pall. J. Plant. Physiol. 2018, 220, 34-42. [CrossRef] [PubMed]

37. Małecka, A.; Derba-Maceluch, M.; Kaczorowska, K.; Piechalak, A.; Tomaszewska, B. Reactive oxygen species production and antioxidative defense system in pea root tissues treated with lead ions: Mitochondrial and peroxisomal level. Acta Physiol. Plant. 2009, 31, 1065-1075. [CrossRef]

38. Calabrese, E. Hormesis: A fundamental concept in biology. Microb. Cell. 2014, 1, 145-149. [CrossRef] [PubMed]

39. Kaiser, J. Sipping from a poisoned chalice. Science 2003, 302, 376-379. [CrossRef] [PubMed]

40. Rucińska, R.; Waplak, S.; Gwóźdź, E. Free radical formation and activity of antioxidantenzymes in lupin root exposed to lead. Plant Physiol. Biochem. 1999, 37, 187-194. [CrossRef] 
41. Sandalio, L.M.; Dalurzo, H.C.; Gómez, M.; Romero-Puertas, M.C.; del Río, L.A. Cadmium-induced changes in the growth and oxidative metabolism of pea plants. J. Exp. Bot. 2001, 52, 2115-2126. [CrossRef] [PubMed]

42. Sobkowiak, R.; Deckert, J. Cadmium-induced changes in growth and cell cycle gene expression in suspension-culture cells of soybean. Plant Physiol. Biochem. 2003, 41,767-772. [CrossRef]

43. Chibuike, G.U.; Obiora, S.C. Heavy metal polluted soils: Effect on plants and bioremediation methods. Appl. Environ. Soil Sci. 2014, 2014, 1-12. [CrossRef]

44. Moreno-Alvarado, M.; García-Morales, S.; Trejo-Téllez, L.I.; Hidalgo-Contreras, J.V.; Gómez-Merino, F.C. Aluminum enhances growth and sugar concentration, alters macronutrient status and regulates the expression of NAC transcription factors in rice. Front. Plant Sci. 2017, 8, 73. [CrossRef] [PubMed]

45. Stebbing, A.R.D. Hormesis-The stimulation of growth by low levels of inhibitors. Sci. Total Environ. 1982, 22, 213-234. [CrossRef]

46. Calabrese, E.J.; Baldwin, L.A. Can the concept of hormesis be generalized to carcinogenesis? Regul. Toxicol. Pharmacol. 1998, 28, 230-241. [CrossRef] [PubMed]

47. Schulz, H. Uber Hefegifte. Pflugers Arch. Gesmate Physiol. Menschen Tiere 1888, 42, 517-541. [CrossRef]

48. Damelin, L.H.; Vokes, S.; Whitcutt, J.M.; Damelin, S.B.; Alexander, J.J. Hormesis: A stress response in cells exposed to low levels of heavy metals. Hum. Exp. Toxicol. 2000, 19, 420-430. [CrossRef] [PubMed]

49. Calabrese, E.; Blain, R. The occurrence of hormetic dose responses in the toxicological literature, the hormesis database: An overview. Toxicol. Appl. Pharmacol. 2005, 202, 289-301. [CrossRef] [PubMed]

50. Calabrese, E.J.; Blain, R.B. Hormesis and plant biology. Environ. Pollut. 2009, 157, 42-48. [CrossRef] [PubMed]

51. Hajiboland, R.; Bahrami Rad, S.; Barceló, J.; Poschenrieder, C. Mechanisms of aluminum-induced growth stimulation in tea (Camellia sinensis). J. Plant Nutr. Soil Sci. 2013, 176, 616-625. [CrossRef]

52. da Silva de Jesus, D.; Machado Martins, F.; Dias de Azevedo Neto, A. Structural changes in leaves and roots are anatomical markers of aluminum sensitivity in sunflower. Pesqui. Agropecu. Trop. 2016, 46, 383-390. [CrossRef]

53. Ghanati, F.; Morita, A.; Yokota, H. Effects of aluminum on the growth of tea plant and activation of antioxidant system. Plant Soil 2005, 276, 133-141. [CrossRef]

54. Watanabe, T.; Jansen, S.; Osaki, M. The beneficial effect of aluminium and the role of citrate in Al accumulation in Melastoma malabathricum. New Phytol. 2004, 165, 773-780. [CrossRef] [PubMed]

55. Du, B.; Nian, H.; Zhang, Z.; Yang, C. Effects of aluminum on superoxide dismutase and peroxidase activities, and lipid peroxidation in the roots and calluses of soybeans differing in aluminum tolerance. Acta Physiol. Plant. 2010, 32, 883-890. [CrossRef]

56. Wang, L.; Fan, X.-W.; Pan, J.-L.; Huang, Z.-B.; Li, Y.-Z. Physiological characterization of maize tolerance to low dose of aluminum, highlighted by promoted leaf growth. Planta 2015, 242, 1391-1403. [CrossRef] [PubMed]

57. Yang, X.E.; Long, X.X.; Ye, H.B.; He, Z.L.; Calvert, D.V.; Stoffella, P.J. Cadmium tolerance and hyperaccumulation in a new Zn-hyperaccumulating plant species (Sedum alfredii Hance). Plant Soil 2004, 259, 181-189. [CrossRef]

58. Liu, W. Viola baoshanensis, a plant that hyperaccumulates cadmium. Chin. Sci. Bull. 2004, 49, 29. [CrossRef]

59. Jia, L.; Liu, Z.; Chen, W.; Ye, Y.; Yu, S.; He, X. Hormesis effects induced by cadmium on growth and photosynthetic performance in a hyperaccumulator, Lonicera japonica Thunb. J. Plant Growth Regul. 2015, 34, 13-21. [CrossRef]

60. Muszyńska, E.; Hanus-Fajerska, E.; Ciarkowska, K. Studies on lead and cadmium toxicity in Dianthus carthusianorum calamine ecotype cultivated in vitro. Plant Biol. 2018, 20, 474-482. [CrossRef] [PubMed]

61. Siddhu, G.; Sirohi, D.S.; Kashyap, K.; Khan, I.A.; Khan, M.A.A. Toxicity of cadmium on the growth and yield of Solanum melongena L. J. Environ. Biol. 2008, 29, 853-857.

62. Qiu, R.-L.; Zhao, X.; Tang, Y.-T.; Yu, F.-M.; Hu, P.-J. Antioxidative response to Cd in a newly discovered cadmium hyperaccumulator, Arabis paniculata F. Chemosphere 2008, 74, 6-12. [CrossRef] [PubMed]

63. Seth, C.S.; Kumar Chaturvedi, P.; Misra, V. The role of phytochelatins and antioxidants in tolerance to Cd accumulation in Brassica juncea L. Ecotoxicol. Environ. Saf. 2008, 71, 76-85. [CrossRef] [PubMed]

64. de la Rosa, G.; Peralta-Videa, J.R.; Montes, M.; Parsons, J.G.; Cano-Aguilera, I.; Gardea-Torresdey, J.L. Cadmium uptake and translocation in tumbleweed (Salsola kali), a potential Cd-hyperaccumulator desert plant species: ICP/OES and XAS studies. Chemosphere 2004, 55, 1159-1168. [CrossRef] [PubMed] 
65. Seth, C.S.; Chaturvedi, P.K.; Misra, V. Toxic effect of arsenate and cadmium alone and in combination on giant duckweed (Spirodela polyrrhiza L.) in response to its accumulation. Environ. Toxicol. 2007, 22, 539-549. [CrossRef] [PubMed]

66. Tang, Y.-T.; Qiu, R.-L.; Zeng, X.-W.; Ying, R.-R.; Yu, F.-M.; Zhou, X.-Y. Lead, zinc, cadmium hyperaccumulation and growth stimulation in Arabis paniculata Franch. Environ. Exp. Bot. 2009, 66, 126-134. [CrossRef]

67. González, C.I.; Maine, M.A.; Cazenave, J.; Sanchez, G.C.; Benavides, M.P. Physiological and biochemical responses of Eichhornia crassipes exposed to Cr (III). Environ. Sci. Pollut. Res. 2015, 22, 3739-3747. [CrossRef] [PubMed]

68. Gardea-Torresdey, J.L.; de la Rosa, G.; Peralta-Videa, J.R.; Montes, M.; Cruz-Jimenez, G.; Cano-Aguilera, I. Differential uptake and transport of trivalent and hexavalent chromium by tumbleweed (Salsola kali). Arch. Environ. Contam. Toxicol. 2005, 48, 225-232. [CrossRef] [PubMed]

69. Paisio, C.E.; Fernandez, M.; González, P.S.; Talano, M.A.; Medina, M.I.; Agostini, E. Simultaneous phytoremediation of chromium and phenol by Lemna minuta Kunth: A promising biotechnological tool. Int. J. Environ. Sci. Technol. 2018, 15, 37-48. [CrossRef]

70. Patnaik, A.R.; Achary, V.M.M.; Panda, B.B. Chromium (VI)-induced hormesis and genotoxicity are mediated through oxidative stress in root cells of Allium cepa L. Plant Growth Regul. 2013, 71, 157-170. [CrossRef]

71. García-Jiménez, A.; Gómez-Merino, F.C.; Tejeda-Sartorius, O.; Trejo-Téllez, L.I. Lanthanum affects bell pepper seedling quality depending on the genotype and time of exposure by differentially modifying plant height, stem diameter and concentrations of chlorophylls, sugars, amino Acids, and proteins. Front. Plant Sci. 2017, 8. [CrossRef] [PubMed]

72. Guo, S.F.; Yu, S.F.; Huang, X.H. Effect of La (III) on some physiological index and ultrastructure of honeysuckle (Lonicera japonica Thunb.). Adv. Mater. Res. 2013, 864-867, 295-298. [CrossRef]

73. Liu, D.; Wang, X.; Zhang, X.; Gao, Z. Effects of lanthanum on growth and accumulation in roots of rice seedlings. Plant Soil Environ. 2013, 59, 196-200. [CrossRef]

74. Xiong, Z.-T. Lead uptake and effects on seed germination and plant growth in a Pb hyperaccumulator Brassica pekinensis Rupr. Bull. Environ. Contam. Toxicol. 1998, 60, 285-291. [CrossRef] [PubMed]

75. Piwowarczyk, B.; Tokarz, K.; Muszyńska, E.; Makowski, W.; Jędrzejczyk, R.; Gajewski, Z.; Hanus-Fajerska, E. The acclimatization strategies of kidney vetch (Anthyllis vulneraria L.) to Pb toxicity. Environ. Sci. Pollut. Res. 2018, 25, 19739-19752. [CrossRef] [PubMed]

76. Lv, S.; Yang, B.; Kou, Y.; Zeng, J.; Wang, R.; Xiao, Y.; Li, F.; Lu, Y.; Mu, Y.; Zhao, C. Assessing the difference of tolerance and phytoremediation potential in mercury contaminated soil of a non-food energy crop, Helianthus tuberosus L. (Jerusalem artichoke). PeerJ 2018, 6, e4325. [CrossRef] [PubMed]

77. Ronchini, M.; Cherchi, L.; Cantamessa, S.; Lanfranchi, M.; Vianelli, A.; Gerola, P.; Berta, G.; Fumagalli, A. Palladium uptake by Pisum sativum: Partitioning and effects on growth and reproduction. Environ. Sci. Pollut. Res. 2015, 22, 7600-7611. [CrossRef] [PubMed]

78. Gawrońska, H.; Przybysz, A.; Szalacha, E.; Pawlak, K.; Brama, K.; Miszczak, A.; Stankiewicz-Kosyl, M.; Gawroński, S.W. Platinum uptake, distribution and toxicity in Arabidopsis thaliana L. plants. Ecotoxicol. Environ. Saf. 2018, 147, 982-989. [CrossRef] [PubMed]

79. Meyer, M.C.; McLendon, T.; Price, D. Evidence of depleted uranium-induced hormesis and differential plant response in three grasses. J. Plant Nutr. 1998, 21, 2475-2484. [CrossRef]

80. Küpper, H.; Zhao, F.J.; McGrath, S.P. Cellular compartmentation of Zinc in leaves of the hyperaccumulator Thlaspi caerulescens. Plant Physiol. 1999, 119, 305-312. [CrossRef]

81. Nascarella, M.A.; Stoffolano, J.G.; Stanek, E.J.; Kostecki, P.T.; Calabrese, E.J. Hormesis and stage specific toxicity induced by cadmium in an insect model, the queen blowfly, Phormia regina Meig. Environ. Pollut. 2003, 124, 257-262. [CrossRef]

82. Ardestani, M.M.; van Gestel, C.A.M. Toxicodynamics of copper and cadmium in Folsomia candida exposed to simulated soil solutions: Copper and cadmium toxicodynamics in springtails. Environ. Toxicol. Chem. 2013, 32, 2746-2754. [CrossRef] [PubMed]

83. Giovanetti, A.; Fesenko, S.; Cozzella, M.L.; Asencio, L.D.; Sansone, U. Bioaccumulation and biological effects in the earthworm Eisenia fetida exposed to natural and depleted uranium. J. Environ. Radioac. 2010, 101, 509-516. [CrossRef] [PubMed]

84. Helmcke, K.J.; Aschner, M. Hormetic effect of methylmercury on Caen orhabditis elegans. Toxicol. Appl. Pharmacol. 2010, 248, 156-164. [CrossRef] [PubMed] 
85. Helmcke, K.J.; Syversen, T.; Miller, D.M.; Aschner, M. Characterization of the effects of methylmercury on Caenorhabditis elegans. Toxicol. Appl. Pharmacol. 2009, 240, 265-272. [CrossRef] [PubMed]

86. Xia, X.; Lin, S.; Zhao, J.; Zhang, W.; Lin, K.; Lu, Q.; Zhou, B. Toxic responses of microorganisms to nickel exposure in farmland soil in the presence of earthworm (Eisenia fetida). Chemosphere 2018, 192, 43-50. [CrossRef] [PubMed]

87. Ayyanath, M.-M.; Cutler, G.C.; Scott-Dupree, C.D.; Sibley, P.K. Transgenerational shifts in reproduction hormesis in green peach aphid exposed to low concentrations of imidacloprid. PLoS ONE 2013, 8, e74532. [CrossRef] [PubMed]

88. Hashmi, M.Z.; Shen, H.; Zhu, S.; Yu, C.; Shen, C. Growth, bioluminescence and shoal behavior hormetic responses to inorganic and/or organic chemicals: A review. Environ. Int. 2014, 64, 28-39. [CrossRef] [PubMed]

89. Calabrese, E.J.; Baldwin, L.A. Chemical hormesis:its historical foundations as a biological hypothesis. Toxicol. Pathol. 1999, 27, 195-216. [CrossRef] [PubMed]

90. Raulin, J. Etudied chimiques sur la vegetation. Ann. Sci. Nat. Bot. 1869, 93-299.

91. Stevens, F.L. The effect of aqueous solutions upon the germination of fungus spores. Bot. Gaz. 1898, 377-406. [CrossRef]

92. Clark, J.F. Electrolytic dissociation and toxic effect. J. Phys. Chem. 1899, 263-316. [CrossRef]

93. Clark, J.F. On the toxic properties of some copper compounds with special reference to Bordeaux mixture. Bot. Gaz. 1902, 26-48. [CrossRef]

94. Clark, J.F. On the toxic effect of deleterious agents on the germination and development of certain filamentous fungi. Bot. Gaz. 1899, 28, 378-404. [CrossRef]

95. Duggar, B.M. Physiological studies with reference to the germination of certain Funous spores. Bot. Gaz. 1901, 38-66. [CrossRef]

96. Collin-Hansen, C.; Andersen, R.A.; Steinnes, E. Damage to DNA and lipids in Boletus edulis exposed to heavy metals. Mycol. Res. 2005, 109, 1386-1396. [CrossRef] [PubMed]

97. Lefcort, H.; Freedman, Z.; House, S.; Pendleton, M. Hormetic effects of heavy metals in aquatic snails: Is a little bit of pollution good? EcoHealth 2008, 5, 10-17. [CrossRef] [PubMed]

98. Becher, M.; Talke, I.N.; Krall, L.; Krämer, U. Cross-species microarray transcript profiling reveals high constitutive expression of metal homeostasis genes in shoots of the zinc hyperaccumulator Arabidopsis halleri. Plant J. 2004, 37, 251-268. [CrossRef] [PubMed]

99. Hall, J.L.; Williams, L.E. Transition metal transporters in plants. J. Exp. Bot. 2003, 54, 2601-2613. [CrossRef] [PubMed]

100. Schat, H.; van Hoof, N.A.L.M.; Tervahauta, A.; Hakvoort, H.W.J.; Chardonnens, A.N.; Koevoets, P.L.M.; Verkleij, J.A.C.; Ernst, W.H.O. Evolutionary responses to zinc and copper stress in Bladder Campion, Silene vulgaris (Moench) Garcke. In Plant Tolerance to Abiotic Stresses: Role of Genetic Engineering; Kluwer Academic Publishers: Dordrecht, The Netherlands, 2000; pp. 343-360.

101. Zhao, F.J.; Wang, J.R.; Barker, J.H.A.; Schat, H.; Bleeker, P.M.; McGrath, S.P. The role of phytochelatins in arsenic tolerance in the hyperaccumulator Pteris vittata. New Phytol. 2003, 159, 403-410. [CrossRef]

102. van Hoof, N.A.; Hassinen, V.H.; Hakvoort, H.W.; Ballintijn, K.F.; Schat, H.; Verkleij, J.A.; Ernst, W.H.; Karenlampi, S.O.; Tervahauta, A.I. Enhanced copper tolerance in Silene vulgaris (Moench) Garcke populations from copper mines is associated with increased transcript levels of a 2b-type metallothionein gene. Plant Physiol. 2001, 126, 1519-1526. [CrossRef] [PubMed]

103. Ahanger, M.A.; Akram, N.A.; Ashraf, M.; Alyemeni, M.N.; Wijaya, L.; Ahmad, P. Plant responses to environmental stresses-From gene to biotechnology. AoB Plants 2017, 9. [CrossRef] [PubMed]

104. Cramer, G.R.; Urano, K.; Delrot, S.; Pezzotti, M.; Shinozaki, K. Effects of abiotic stress on plants: A systems biology perspective. BMC Plant. Biol. 2011, 11, 163. [CrossRef] [PubMed]

105. Dinneny, J.R.; Long, T.A.; Wang, J.Y.; Jung, J.W.; Mace, D.; Pointer, S.; Barron, C.; Brady, S.M.; Schiefelbein, J.; Benfey, P.N. Cell identity mediates the response of Arabidopsis roots to abiotic stress. Science 2008, 320, 942-945. [CrossRef] [PubMed]

106. Arasimowicz-Jelonek, M.; Floryszak-Wieczorek, J.; Drzewiecka, K.; Chmielowska-Bąk, J.; Abramowski, D.; Izbiańska, K. Aluminum induces cross-resistance of potato to Phytophthora infestans. Planta 2014, 239, 679-694. [CrossRef] [PubMed] 
107. Chmielowska, J.; Veloso, J.; Gutiérrez, J.; Silvar, C.; Díaz, J. Cross-protection of pepper plants stressed by copper against a vascular pathogen is accompanied by the induction of a defence response. Plant. Sci. 2010, 178, 176-182. [CrossRef]

108. Barcelo, J.; Poschenrieder, C. Fast root growth responses, root exudates, and internal detoxification as clues to the mechanisms of aluminium toxicity and resistance: A review. Environ. Exp. Bot. 2002, 48, 75-92. [CrossRef]

109. Steinberg, C.E.W. Stress Ecology: Environmental Stress as Ecological Driving Force and Key Player in Evolution; Springer: London, UK, 2012; ISBN 978-94-007-2071-8.

110. Pollard, A.J.; Baker, A.J.M. Deterrence of herbivory by zinc hyperaccumulation in Thlaspi caerulescens (Brassicae). New Phytol. 1997, 135, 655-658. [CrossRef]

111. Jonak, C.; Nakagami, H.; Hirt, H. Heavy Metal Stress. Activation of Distinct Mitogen-Activated Protein Kinase Pathways by Copper and Cadmium. Plant Physiol. 2004, 136, 3276-3283. [CrossRef] [PubMed]

112. Nakagami, H.; Pitzschke, A.; Hirt, H. Emerging MAP kinase pathways in plant stress signalling. Trends Plant. Sci. 2005, 10, 339-346. [CrossRef] [PubMed]

113. Boyd, R.S.; Martens, S.N. The raison d'etre for metal hyperaccumulation by plants. In The Vegetation of Ultramafic (Serpentine) Soils; Intercept: Andover, MA, USA, 1992; pp. 279-289.

114. Tolrà, R.P.; Poschenrieder, C.; Alonso, R.; Barceló, D.; Barceló, J. Influence of zinc hyperaccumulation on glucosinolates in Thlaspi caerulescens. New Phytol. 2001, 151, 621-626. [CrossRef]

115. Rout, G.R.; Panigrahi, J. Analysis of Signaling Pathways during Heavy Metal Toxicity: A Functional Genomics Perspective. In Elucidation of Abiotic Stress Signaling in Plants; Springer: New York, NY, USA, 2015; pp. 295-322, ISBN 978-1-4939-2539-1.

116. Tiwari, S.; Lata, C. Heavy Metal Stress, Signaling, and Tolerance Due to Plant-Associated Microbes: An Overview. Front. Plant. Sci. 2018, 9. [CrossRef] [PubMed]

117. Vollenweider, P.; Günthardt-Goerg, M.S. Diagnosis of abiotic and biotic stress factors using the visible symptoms in foliage. Environ. Pollut. 2005, 137, 455-465. [CrossRef] [PubMed]

118. Llugany, M.; Martin, S.R.; Barceló, J.; Poschenrieder, C. Endogenous jasmonic and salicylic acids levels in the Cd-hyperaccumulator Noccaea (Thlaspi) praecox exposed to fungal infection and/or mechanical stress. Plant. Cell. Rep. 2013, 32, 1243-1249. [CrossRef] [PubMed]

119. Fones, H.N.; Eyles, C.J.; Bennett, M.H.; Smith, J.A.C.; Preston, G.M. Uncoupling of reactive oxygen species accumulation and defence signalling in the metal hyperaccumulator plant Noccaea caerulescens. New Phytol. 2013, 199, 916-924. [CrossRef] [PubMed]

120. Sivaguru, M.; Ezaki, B.; He, Z.-H.; Tong, H.; Osawa, H.; Baluška, F.; Volkmann, D.; Matsumoto, H. Aluminum-Induced Gene Expression and Protein Localization of a Cell Wall-Associated Receptor Kinase in Arabidopsis. Plant Physiol. 2003, 132, 2256-2266. [CrossRef] [PubMed]

121. Suzuki, N.; Koizumi, N.; Sano, H. Screening of cadmium-responsive genes in Arabidopsis thaliana. Plant Cell Environ. 2001, 24, 1177-1188. [CrossRef]

122. Maksymiec, W.; Wianowska, D.; Dawidowicz, A.L.; Radkiewicz, S.; Mardarowicz, M.; Krupa, Z. The level of jasmonic acid in Arabidopsis thaliana and Phaseolus coccineus plants under heavy metal stress. J. Plant Physiol. 2005, 162, 1338-1346. [CrossRef] [PubMed]

123. Freeman, J.L.; Garcia, D.; Kim, D.; Hopf, A.; Salt, D.E. Constitutively elevated salicylic acid signals glutathione-mediated nickel tolerance in Thlaspi nickel hyperaccumulators. Plant Physiol. 2005, 137, 1082-1091. [CrossRef] [PubMed]

124. Peleg, Z.; Blumwald, E. Hormone balance and abiotic stress tolerance in crop plants. Curr. Opin. Plant Biol. 2011, 14, 290-295. [CrossRef] [PubMed]

125. Hörger, A.C.; Fones, H.N.; Preston, G.M. The current status of the elemental defense hypothesis in relation to pathogens. Front. Plant Sci. 2013, 4. [CrossRef] [PubMed]

126. Rascio, N.; Navari-Izzo, F. Heavy metal hyperaccumulating plants: How and why do they do it? And what makes them so interesting? Plant Sci. 2011, 180, 169-181. [CrossRef] [PubMed]

127. Jhee, E.M.; Boyd, R.S.; Eubanks, M.D. Nickel hyperaccumulation as an elemental defense of Streptanthus polygaloides (Brassicaceae): Influence of herbivore feeding mode. New Phytol. 2005, 168, 331-344. [CrossRef] [PubMed]

128. Martens, S.N.; Boyd, R.S. The ecological significance of nickel hyperaccumulation: A plant chemical defense. Oecologia 1994, 98, 379-384. [CrossRef] [PubMed] 
129. Boyd, R.S. The defense hypothesis of elemental hyperaccumulation: Status, challenges and new directions. Plant Soil 2007, 293, 153-176. [CrossRef]

130. Jiang, R.F.; Ma, D.Y.; Zhao, F.J.; McGrath, S.P. Cadmium hyperaccumulation protects Thlaspi caerulescens from leaf feeding damage by thrips (Frankliniella occidentalis). New Phytol. 2005, 167, 805-814. [CrossRef] [PubMed]

131. Behmer, S.T.; Lloyd, C.M.; Raubenheimer, D.; Stewart-Clark, J.; Knight, J.; Leighton, R.S.; Harper, F.A.; Smith, J.A.C. Metal hyperaccumulation in plants: Mechanisms of defence against insect herbivores. Funct. Ecol. 2005, 19, 55-66. [CrossRef]

132. Rathinasabapathi, B.; Rangasamy, M.; Froeba, J.; Cherry, R.H.; McAuslane, H.J.; Capinera, J.L.; Srivastava, M.; Ma, L.Q. Arsenic hyperaccumulation in the Chinese brake fern (Pteris vittata) deters grasshopper (Schistocerca americana) herbivory. New Phytol. 2007, 175, 363-369. [CrossRef] [PubMed]

133. Galeas, M.L.; Klamper, E.M.; Bennett, L.E.; Freeman, J.L.; Kondratieff, B.C.; Quinn, C.F.; Pilon-Smits, E.A.H. Selenium hyperaccumulation reduces plant arthropod loads in the field. New Phytol. 2008, 177, 715-724. [CrossRef] [PubMed]

134. Martens, S.N.; Boyd, R.S. The defensive role of Ni hyperaccumulation by plants: A field experiment. Am. J. Bot. 2002, 89, 998-1003. [CrossRef] [PubMed]

135. Boyd, R.S. High-nickel insects and nickel hyperaccumulator plants: A review. Insect Sci. 2009, 16, 19-31. [CrossRef]

136. Wall, M.A.; Boyd, R.S.; Cook, J. Melanotrichus boydi (hemiptera: Miridae) is a specialist on the nickel hyperaccumulator streptanthus polygaloides (brassicaceae). Southwest. Nat. 2006, 51, 481-489. [CrossRef]

137. Boyd, R.S. Plant defense using toxic inorganic ions: Conceptual models of the defensive enhancement and joint effects hypotheses. Plant Sci. 2012, 195, 88-95. [CrossRef] [PubMed]

138. Boyd, R.S.; Moar, W.J. The defensive function of Ni in plants: Response of the polyphagous herbivore Spodoptera exigua (Lepidoptera: Noctuidae) to hyperaccumulator and accumulator species of Streptanthus (Brassicaceae). Oecologia 1999, 118, 218-224. [CrossRef] [PubMed]

139. Cheruiyot, D.J.; Boyd, R.S.; Coudron, T.A.; Cobine, P.A. Biotransfer, bioaccumulation and effects of herbivore dietary $\mathrm{Co}, \mathrm{Cu}, \mathrm{Ni}$, and $\mathrm{Zn}$ on growth and development of the insect predator Podisus maculiventris (Say). J. Chem. Ecol. 2013, 39, 764-772. [CrossRef] [PubMed]

140. Noret, N.; Meerts, P.; Tolrà, R.; Poschenrieder, C.; Barceló, J.; Escarre, J. Palatability of Thlaspi caerulescens for snails: Influence of zinc and glucosinolates. New Phytol. 2005, 165, 763-771. [CrossRef] [PubMed]

141. Winter, T.R.; Borkowski, L.; Zeier, J.; Rostás, M. Heavy metal stress can prime for herbivore-induced plant volatile emission: Copper primes VOCs. Plant Cell Environ. 2012, 35, 1287-1298. [CrossRef] [PubMed]

142. Wise, M.J.; Kieffer, D.L.; Abrahamson, W.G. Costs and benefits of gregarious feeding in the meadow spittlebug, Philaenus spumarius. Ecol. Entomol. 2006, 31, 548-555. [CrossRef]

143. Baghban, A.; Sendi, J.J.; Zibaee, A.; Khosravi, R. Effect of heavy metals (Cd, Cu and Zn) on feeding indices and energy reserves of the cotton boll worm Helicoverpa armigera Hübner (Lepidoptera: Noctuidae). J. Plant Protec. Res. 2014, 54, 367-373. [CrossRef]

144. Trumble, J.T.; Jensen, P.D. Ovipositional response, developmental effects and toxicity of hexavalent chromium to Megaselia scalaris, a terrestrial detritivore. Arch. Environ. Contam. Toxicol. 2004, 46, 372-376. [CrossRef] [PubMed]

145. Emre, I.; Kayis, T.; Coskun, M.; Dursun, O.; Cogun, H.Y. Changes in antioxidative enzyme activity, glycogen, lipid, protein, and malondialdehyde content in cadmium-treated Galleria mellonella larvae. Ann. Entomol. Soc. Am. 2013, 106, 371-377. [CrossRef]

146. Sun, H.-X.; Dang, Z.; Xia, Q.; Tang, W.-C.; Zhang, G.-R. The effect of dietary nickel on the immune responses of Spodoptera litura Fabricius larvae. J. Insect Physiol. 2011, 57, 954-961. [CrossRef] [PubMed]

147. Satapathy, P.; Achary, V.M.M.; Panda, B.B. Aluminum-induced abiotic stress counteracts Fusarium infection in Cajanus cajan (L.) Millsp. J. Plant. Interact. 2012, 7, 121-128. [CrossRef]

148. Mittra, B.; Ghosh, P.; Henry, S.L.; Mishra, J.; Das, T.K.; Ghosh, S.; Babu, C.R.; Mohanty, P. Novel mode of resistance to Fusarium infection by a mild dose pre-exposure of cadmium in wheat. Plant Physiol. Biochem. 2004, 42, 781-787. [CrossRef] [PubMed]

149. Mohapatra, S.; Mittra, B. Protein glutathionylation protects wheat (Triticum aestivum Var. Sonalika) against Fusarium induced oxidative stress. Plant Physiol. Biochem. 2016, 109, 319-325. [CrossRef] [PubMed] 
150. Cabot, C.; Gallego, B.; Martos, S.; Barceló, J.; Poschenrieder, C. Signal cross talk in Arabidopsis exposed to cadmium, silicon, and Botrytis cinerea. Planta 2013, 237, 337-349. [CrossRef] [PubMed]

151. Yao, Y.A.; Wang, J.; Ma, X.; Lutts, S.; Sun, C.; Ma, J.; Yang, Y.; Achal, V.; Xu, G. Proteomic analysis of Mn-induced resistance to powdery mildew in grapevine. J. Exp. Bot. 2012, 63, 5155-5170. [CrossRef] [PubMed]

152. Ghaderian, Y.S.M.; Lyon, A.J.E.; Baker, A.J.M. Seedling mortality of metal hyperaccumulator plants resulting from damping off by Pythium spp.: Research seedling mortality of hyperaccumulator plants. New Phytol. 2000, 146, 219-224. [CrossRef]

153. Hanson, B. Selenium accumulation protects Brassica juncea from invertebrate herbivory and fungal infection. New Phytol. 2003, 159, 461-469. [CrossRef]

154. Hanson, B.; Lindblom, S.D.; Loeffler, M.L.; Pilon-Smits, E.A.H. Selenium protects plants from phloem-feeding aphids due to both deterrence and toxicity. New Phytol. 2004, 162, 655-662. [CrossRef]

155. Nummelin, M.; Lodenius, M.; Tulisalo, E.; Hirvonen, H.; Alanko, T. Predatory insects as bioindicators of heavy metal pollution. Environ. Pollut. 2007, 145, 339-347. [CrossRef] [PubMed]

156. Zhuang, P.; Zou, H.; Shu, W. Biotransfer of heavy metals along a soil-plant-insect-chicken food chain: Field study. J. Environ. Sci. 2009, 21, 849-853. [CrossRef]

157. Leita, L.; Enne, G.; De Nobili, M.; Baldini, M.; Sequi, P. Heavy metal bioaccumulation in lamb and sheep bred in smelting and mining areas of S.W. sardinia (Italy). Bull. Environ. Contam. Toxicol. 1991, 46, 887-893. [CrossRef] [PubMed]

158. Goodyear, K.; McNeill, S. Bioaccumulation of heavy metals by aquatic macro-invertebrates of different feeding guilds: A review. Sci. Total Environ. 1999, 229, 1-19. [CrossRef]

159. Zhang, Z.-S.; Lu, X.-G.; Wang, Q.-C.; Zheng, D.-M. Mercury, cadmium and lead biogeochemistry in the soil-plant-insect system in Huludao City. Bull. Environ. Contam. Toxicol. 2009, 83, 255-259. [CrossRef] [PubMed]

160. Wan, T.-L.; Liu, S.; Tang, Q.-Y.; Cheng, J.-A. Heavy Metal Bioaccumulation and Mobility from Rice Plants to Nilaparvata lugens (Homoptera: Delphacidae) in China. Environ. Entomol. 2014, 43, 654-661. [CrossRef] [PubMed]

161. Warrington, $\mathrm{S}$. Relationship between $\mathrm{SO}_{2}$ dose and growth of the pea aphid, Acyrthosiphon pisum, on peas. Environ. Pollut. 1987, 43, 155-162. [CrossRef]

162. van Ooik, T.; Rantala, M.J.; Saloniemi, I. Diet-mediated effects of heavy metal pollution on growth and immune response in the geometrid moth Epirrita autumnata. Environ. Pollut. 2007, 145, 348-354. [CrossRef] [PubMed]

163. van Ooik, T. Effects of Heavy Metal Pollution and Host Plant Leaf Chemistry on the Immune Defense and Life History Traits of An Insect Herbivore; Painosalama Oy: Turku, Finland, 2008.

164. El-Sheikh, E.-S.A.; Kamita, S.G.; Vu, K.; Hammock, B.D. Improved insecticidal efficacy of a recombinant baculovirus expressing mutated JH esterase from Manduca sexta. Biol. Control 2011, 58, 354-361. [CrossRef]

165. Mitterboeck, F.; Fuehrer, E. Effects of fluoride-polluted spruce leaves on nun moth caterpillars (Lymantria monacha). J. Appl. Entomol. 1988, 105, 19-27.

166. Zhang, Y.; Lambiase, S.; Fasola, M.; Gandini, C.; Grigolo, A.; Laudani, U. Mortality and tissue damage by heavy metal contamination in the German cockroach, Blattella germanica (Blattaria, Blattellidae). Ital. J. Zool. 2001, 68, 137-145. [CrossRef]

167. Rayms-Keller, A.; Olson, K.E.; McGaw, M.; Oray, C.; Carlson, J.O.; Beaty, B.J. Effect of heavy metals on Aedes aegypti (Diptera:Culicidae) larvae. Ecotoxicol. Environ. Saf. 1998, 39, 41-47. [CrossRef] [PubMed]

168. Dom, N.C.; Ahmad, P.; Mokhtar, M.A.M.; Rajan, S. Assessment of heavy metal concentration on Aedes mosquito breeding sites in urban area, Malaysia. Int. J. Mosq. Res. 2017, 4, 12-19.

169. Fountain, M.T.; Hopkin, S.P. Continuous monitoring of Folsomia candida (Insecta: Collembola) in a metal exposure test. Ecotoxicol. Environ. Saf. 2001, 48, 275-286. [CrossRef] [PubMed]

170. Ilijin, L.; Periać-Mataruga, V.; Radojičić, R.; Lazarević, J.; Nenadović, V.; Vlahović, M.; Mrdaković, M. Effects of cadmium on protocerebral neurosecretory neurons and fitness components in Lymantria dispar L. Folia Biol. 2009, 58, 91-99. [CrossRef]

171. Mogren, C.L.; Trumble, J.T. The impacts of metals and metalloids on insect behavior. Entomol. Exp. Appl. 2010, 135, 1-17. [CrossRef] 
172. Posthuma, L.; Van Straalen, N.M. Heavy-metal adaptation in terrestrial invertebrates: A review of occurrence, genetics, physiology and ecological consequences. Comp. Biochem. Physiol. Part C Pharmacol. Toxicol. Endocrinol. 1993, 106, 11-38. [CrossRef]

173. Xie, L.; Klerks, P.L. Fitness cost of resistance to cadmium in the least killifish (Heterandria formosa). Environ. Toxicol. Chem. 2004, 23, 1499-1503. [CrossRef] [PubMed]

174. Bahrndorff, S.; Holmstrup, M.; Petersen, H.; Loeschcke, V. Geographic variation for climatic stress resistance traits in the springtail Orchesella cincta. J. Insect Physiol. 2006, 52, 951-959. [CrossRef] [PubMed]

175. Wilczek, G.; Kramarz, P.; Babczyńska, A. Activity of carboxylesterase and glutathione S-transferase in different life-stages of carabid beetle (Poecilus cupreus) exposed to toxic metal concentrations. Comp. Biochem. Physiol. C Toxicol. Pharmacol. 2003, 134, 501-512. [CrossRef]

176. Morgan, A.J.; Kille, P.; Stürzenbaum, S.R. Microevolution and ecotoxicology of metals in invertebrates. Environ. Sci. Technol. 2007, 41, 1085-1096. [CrossRef] [PubMed]

177. van Ooik, T.; Rantala, M.J. Local adaptation of an insect herbivore to a heavy metal contaminated environment. Ann. Zool. Fennici 2010, 47, 215-222. [CrossRef]

178. Ben-Shahar, Y. The impact of environmental Mn exposure on insect biology. Front. Genet. 2018, 9. [CrossRef] [PubMed]

179. Sovik, E.; Perry, C.J.; LaMora, A.; Barron, A.B.; Ben-Shahar, Y. Negative impact of manganese on honeybee foraging. Biol. Lett. 2015, 11, 20140989. [CrossRef] [PubMed]

180. Kafel, A.; Rozpędek, K.; Szulińska, E.; Zawisza-Raszka, A.; Migula, P. The effects of cadmium or zinc multigenerational exposure on metal tolerance of Spodoptera exigua (Lepidoptera: Noctuidae). Environ. Sci. Pollut. Res. 2014, 21, 4705-4715. [CrossRef] [PubMed]

181. Mirčić, D.; Blagojević, D.; Perić-Mataruga, V.; Ilijin, L.; Mrdaković, M.; Vlahović, M.; Lazarević, J. Cadmium effects on the fitness-related traits and antioxidative defense of Lymantria dispar L. larvae. Environ. Sci. Pollut. Res. 2013, 20, 209-218. [CrossRef] [PubMed]

182. Wu, G.-X.; Ye, G.-Y.; Hu, C.; Cheng, J.-A. Accumulation of cadmium and its effects on growth, development and hemolymph biochemical compositions in Boettcherisca peregrina larvae (Diptera: Sarcophagidae). Insect Sci. 2006, 13, 31-39. [CrossRef]

183. Suganya, M.; Karthi, S.; Subramanian Shivakumar, M. Effect of cadmium and lead exposure on tissue specific antioxidant response in Spodoptera litura. Free Radic. Antioxid. 2016, 6, 90-100. [CrossRef]

184. Al-Momani, F.A.; Massadeh, A.M. Effect of different heavy-metal concentrations on Drosophila melanogaster larval growth and development. Biol. Trace Elem. Res. 2005, 108, 271-277. [CrossRef]

185. Shulman, M.V.; Pakhomov, O.Y.; Brygadyrenko, V.V. Effect of lead and cadmium ions upon the pupariation and morphological changes in Calliphora vicina (Diptera, Calliphoridae). Folia Oecol. 2017, 44, $28-37$. [CrossRef]

186. Safaee, S.; Feridoni, M.; Mahadavi-Ahdavi, N.; Haddad, F.; Mirshamsi, O. Effects of lead on the development of Drosophila melanogaster. Period. Biol. 2014, 116, 259-265.

187. Haq, R. Adverse effect of lead acetate on Drosophila melanogaster. J. Basic Appl. Sci. 2011, 157-163. [CrossRef]

188. Fouda, M.; Hassan, M.I.; El-Sheikh, T.; Abd-Elgaphar, A.; Hasaballah, A. Histopathological effect of certain heavy metals on the mosquito vector Culex pipiens (Diptera:Culcidae). Al-Azhar Bull. Sci. 2011, 22, 69-83.

189. Zaman, K.; MacGill, R.S.; Johnson, J.E.; Ahmad, S.; Pardini, R.S. An insect model for assessing mercury toxicity: Effect of mercury on antioxidant enzyme activities of the housefly (Musca domestica) and the cabbage looper moth (Trichoplusia ni). Arch. Environ. Contam. Toxicol. 1994, 26, 114-118. [CrossRef] [PubMed]

190. Xie, L.; Flippin, J.L.; Deighton, N.; Funk, D.H.; Dickey, D.A.; Buchwalter, D.B. Mercury(II) bioaccumulation and antioxidant physiology in four aquatic insects. Environ. Sci. Technol. 2009, 43, 934-940. [CrossRef] [PubMed]

191. Kafel, A.; Nadgórska-Socha, A.; Gospodarek, J.; Babczyńska, A.; Skowronek, M.; Kandziora, M.; Rozpędek, K. The effects of Aphis fabae infestation on the antioxidant response and heavy metal content in field grown Philadelphus coronarius plants. Sci. Total Environ. 2010, 408, 1111-1119. [CrossRef] [PubMed]

192. Borowska, J.; Pyza, E. Effects of heavy metals on insect immunocompetent cells. J. Insect Physiol. 2011, 57, 760-770. [CrossRef] [PubMed]

193. Yu, Y.; Shen, G.; Zhu, H.; Lu, Y. Imidacloprid-induced hormesis on the fecundity and juvenile hormone levels of the green peach aphid Myzus persicae (Sulzer). Pest. Biochem. Physiol. 2010, 98, 238-242. [CrossRef] 
194. Yusmalinar, S.; Anggraeni, T.; Kustiati, K.; Wibowo, I.; Eka Putra, R.; Ahmad, I. Reproductive ability enhancement of housefly (Musca domestica Linn) (Diptera: Muscidae) through hormesis by application of sublethal doses of imidacloprid and permethrin. J. Entomol. 2017, 14, 199-207. [CrossRef]

195. Rabhi, K.K.; Esancy, K.; Voisin, A.; Crespin, L.; Le Corre, J.; Tricoire-Leignel, H.; Anton, S.; Gadenne, C. Unexpected effects of low doses of a neonicotinoid insecticide on behavioral responses to sex pheromone in a pest insect. PLoS ONE 2014, 9, e114411. [CrossRef] [PubMed]

196. Sashindran Nair, K.; Vijayan, V.A.; Nair, J.S.; Trivedy, K.; Chinya, P.K. Hormetic influence on silkworm, Bombyx mori L., of the phytojuvenoid $\omega$-formyl longifolene oxime propargyl ether. Int. J. Trop. Insect Sci. 2002, 22, 145-150. [CrossRef]

197. Morse, J.G. Agricultural implications of pesticide- induced hormesis of insects and mites. Hum. Exp. Toxicol. 1998, 17, 266-269. [CrossRef] [PubMed]

198. Gong, Y.; Xu, B.; Zhang, Y.; Gao, X.; Wu, Q. Demonstration of an adaptive response to preconditioning Frankliniella occidentalis (Pergande) to sublethal doses of spinosad: A hormetic-dose response. Ecotoxicology 2015, 24, 1141-1151. [CrossRef] [PubMed]

199. Cutler, G.C. Insects, insecticides and hormesis: Evidence and considerations for study. Dose-Response 2013, 11. [CrossRef] [PubMed]

200. Chen, X.D.; Seo, M.; Stelinski, L.L. Behavioral and hormetic effects of the butenolide insecticide, flupyradifurone, on Asian citrus psyllid, Diaphorina citri. Crop Protec. 2017, 98, 102-107. [CrossRef]

201. Ayyanath, M.-M.; Cutler, G.C.; Scott-Dupree, C.D.; Prithiviraj, B.; Kandasamy, S.; Prithiviraj, K. Gene expression during imidacloprid-induced hormesis in green peach aphid. Dose-Response 2014, 12. [CrossRef] [PubMed]

202. Ayyanath, M.-M.; Scott-Dupree, C.D.; Cutler, G.C. Effect of low doses of precocene on reproduction and gene expression in green peach aphid. Chemosphere 2015, 128, 245-251. [CrossRef] [PubMed]

203. Guedes, R.N.C.; Cutler, G.C. Insecticide-induced hormesis and arthropod pest management: Insecticide-induced hormesis. Pest Manag. Sci. 2014, 70, 690-697. [CrossRef] [PubMed]

204. Merrington, G.; Miller, D.; McLaughlin, M.J.; Keller, M.A. Trophic barriers to fertilizer Cd bioaccumulation through the food chain: A case study using a plant-insect predator pathway. Arch. Environ. Contam. Toxicol. 2001, 41, 151-156. [CrossRef] [PubMed]

205. Görür, G. Developmental instability in cabbage aphid (Brevicoryne brassicae) populations exposed to heavy metal accumulated host plants. Ecol. Indic. 2006, 6, 743-748. [CrossRef]

206. Görür, G. Zinc and cadmium accumulation in cabbage aphid (Brevicoryne brassicae) host plants and developmental instability. Insect Sci. 2009, 16, 65-71. [CrossRef]

207. Maryański, M.; Kramarz, P.; Laskowski, R.; Nikilińska, M. Decreased energetic reserves, morphological changes and accumulation of metals in carabid beetles (Poecilus cupreus L.) exposed to zinc- or cadmium-contaminated food. Ecotoxicology 2001, 11, 127-139.

208. Ernst, W.H.O. Effects of heavy metals in plants at the cellulr and organismic level. In Bioaccumulation and Biological Effects of Chemicals; John Wiley \& Sons: Hoboken, NJ, USA, 1998.

209. Görür, G. Effects of host plant contaminated with heavy metals on the life history traits of aphids (Breyicoryne brassicae L.). Pol. J. Ecol. 2007, 55, 113-120.

210. Culliney, T.W.; Pimentel, D. Ecological effects of organic agricultural practices on insect populations. Agric. Ecosyst. Environ. 1986, 15, 253-266. [CrossRef]

211. Jaworska, M.; Gospodarek, J. Changes in population of pests and beneficial insects caused by soil contamination with heavy metals. Chemia i Inżynieria Ekologiczna 2000, 7, 1143-1151.

212. Jaworska, M.; Gospodarek, J. Aphid (Aphis fabae Scop.) occurence on broan beans (Vicia faba L. ssp Maior) depending on liming and magnesium treatment of soil contaminated with heavy metals. Acta Agrophys. 2003, 1, 647-652.

213. Stolpe, C.; Giehren, F.; Krämer, U.; Müller, C. Both heavy metal-amendment of soil and aphid-infestation increase $\mathrm{Cd}$ and $\mathrm{Zn}$ concentrations in phloem exudates of a metal-hyperaccumulating plant. Phytochemistry 2017, 139, 109-117. [CrossRef] [PubMed]

214. Crawford, L.A.; Lepp, N.W.; Hodkinson, I.D. Accumulation and egestion of dietary copper and cadmium by the grasshopper Locusta mihratoria R\&F (Orthoptera:Arcididae). Environ. Pollut. 1996, 92, 241-246. [PubMed]

215. Boyd, R.S.; Martens, S.N. Aphids are unaffected by the elemental defence of the nickel hyperaccumulator Streptanthus polygaloides (Brassicaceae). Chemoecology 1999, 9, 1-7. [CrossRef] 
216. Cuero, R.; Ouellet, T.; Yu, J.; Mogongwa, N. Metal ion enhancement of fungal growth, gene expression and aflatoxin synthesis in Aspergillus flavus: RT-PCR characterization: Metal ions on gungal grwoth, gene expression and aflatoxin synthesis. J. Appl. Microbiol. 2003, 94, 953-961. [CrossRef] [PubMed]

217. Englander, C.M.; Corden, M.E. Stimulation of mycelial growth of Endothia parasitica by heavy metals. Appl. Microbiol. 1971, 22, 1012-1016. [PubMed]

218. Golubovic Curguz, V.; Raicevic, V.; Tabakovic Tosic, M.; Veselinovic, M.; Jovanovic, L.J. Same physiological characteristics of three ectomycorrhizal fungi from Suillus genus. Miner. Biotecnol. 2010, 22, 1-7.

219. Hartikainen, E.S.; Lankinen, P.; Rajasärkkä, J.; Koponen, H.; Virta, M.; Hatakka, A.; Kähkönen, M.A. Impact of copper and zinc on the growth of saprotrophic fungi and the production of extracellular enzymes. Boreal Environ. Res. 2012, 17, 210-218.

220. Hartikainen, E.S.; Hatakka, A.; Kahkonen, M.A. Impact of cadmium, chromium, cobalt, lithium and manganese to the growth of fungi and production of enzymes. Expert Opin. Environ. Biol. 2013, 2. [CrossRef]

221. Abu-Mejdad, N.M.J.A. Response of some fungal species to the effect of copper, magnesium and zinc under the laboratory condition. Eur. J. Exp. Biol. 2013, 3, 535-540.

222. Binsadiq, A.; Al-Rahmah, A. Growth of Podaxis pistilaria collected from Saudi Arabia at different concentrations of cadmium and lead. J. King Saudi Univ. Sci. 1993, 5, 127-135.

223. Anahid, S.; Yaghmaei, S.; Ghobadinejad, Z. Heavy metal tolerance of fungi. Sci. Iran. 2011, 18, 502-508. [CrossRef]

224. Whipps, J.M. Microbial interactions and biocontrol in the rhizosphere. J. Exp. Bot. 2001, 52, 487-511. [CrossRef] [PubMed]

225. Rudawska, M.; Kieliszewska-Rokicka, B.; Leski, T. Effect of aluminium on Pinus sylvestris seedlings mycorrhizal with aluminium-tolerant and aluminium-sensitive strains of Suillus luteus. Dendrobiology 2000, 45, 89-96.

226. Carter, M.R. Seedling growth and mineral nutrition of Scots pine under acidic to calcareous soil condition. Soil Sci. 1987, 144, 175-180. [CrossRef]

227. Puhe, J. Growth and development of the root system of Norway spruce (Picea abies) in forest stands-A review. For. Ecol. Manag. 2003, 175, 253-273. [CrossRef]

228. Kieliszewska-Rokicka, B.; Kurczyńska, E.U.; Leski, T. Physiological activity of ectomycorrhizas in a moderately polluted forest (Ratanica catchment, southern Poland). Dendrobiology 2000, 45, 47-59.

229. Agrios, G.N. Plant Pathology, 5th ed.; Academic Press: San Diego, CA, USA, 1997.

230. van West, A.; Appiah, A.A.; Gow, N.A.R. Advances in research on oomycete root pathogens. Physiol. Mol. Plant Pathol. 2003, 62, 99-113. [CrossRef]

231. Stroiński, A.; Floryszak-Wieczorek, J. Effect of cadmium on the host-Pathogen system. III. Influence of cadmium and Phytophthora infestans on membrane permeability of potato leaves. Biochem. Physiol. Pflanz. 1990, 186, 417-421. [CrossRef]

232. Stroiński, A.; Floryszak-Wieczorek, J. Effects of cadmium on the host-pathogen system. IV. Influence of cadmium and Phytophthora infestans on membrane permeability of potato tuber. J. Plant Physiol. 1993, 142, 575-578. [CrossRef]

233. Zhang, Q.; Zeng, G.; Chen, G.; Yan, M.; Chen, A.; Du, J.; Huang, J.; Yi, B.; Zhou, Y.; He, X.; et al. The effect of heavy metal-induced oxidative stress on the enzymes in white rot fungus Phanerochaete chrysosporium. Appl. Biochem. Biotechnol. 2015, 175, 1281-1293. [CrossRef] [PubMed]

234. Gadd, G.M. Interactions of fungi with toxic metals. In The Genus Aspergillus; Federation of European Microbiological Societies Symposium Series; Springer: Boston, MA, USA, 1994; pp. 361-374, ISBN 978-1-4899-0983-1.

235. Hasanzadeh, M.; Mohammadifar, M.; Norabadi, M.T.; Dashtipoor, S.; Sahebani, N.; Etebarian, H.R. The effect of different salts (heavy metals) on the mycelium growth of Nematophagus fungi. Arch. Phytopathol. Plant Prot. 2012, 45, 2087-2094. [CrossRef]

236. Gąsecka, M.; Rzymski, P.; Mleczek, M.; Siwulski, M.; Budzyńska, S.; Magdziak, Z.; Niedzielski, P.; Sobieralski, K. The relationship between metal composition, phenolic acid and flavonoid content in Imleria badia from non-polluted and polluted areas. J. Environ. Sci. Health B 2017, 52, 171-177. [CrossRef] [PubMed]

237. Southam, C.M.; Ehrlich, J. Effects of extracts of western red-cedar heartwood on certain wood-decaying fungi in culture. Phytopathology 1943, 33, 517-524.

238. Hessayon, D.G. Double-action of trichothecin and its production in soil. Nature 1953, 167, 998-999. [CrossRef] 
239. Garzón, C.D.; Molineros, J.E.; Yánez, J.M.; Flores, F.J.; del Mar Jiménez-Gasco, M.; Moorman, G.W. Sublethal doses of mefenoxam enhance Pythium damping-off of Geranium. Plant Dis. 2011, 95, 1233-1238. [CrossRef]

240. Baraldi, E.; Mari, M.; Chierici, E.; Pondrelli, M.; Bertolini, P.; Pratella, G.C. Studies on thiabendazole resistance of Penicillium expansum of pears: Pathogenic fitness and genetic characterization. Plant Pathol. 2003, 52, 362-370. [CrossRef]

241. Landry, J.; Martinez, C.; Rochefort, L. The use of fungicide Nova to mitigate infection of Sphagnum by parasitic fungi in the greenhouse. Botany 2011, 89, 655-661. [CrossRef]

242. Moorman, G.W.; Kim, S.H. Species of Pythium from greenhouses in Pennsylvania exhibit resistance to propamocarb and mefenoxam. Plant Dis. 2004, 88, 630-632. [CrossRef]

243. Zhang, S.; Panaccione, D.G.; Gallegly, M.E. Metalaxyl stimulation of growth of isolates of Phytophthora infestans. Mycologia 1997, 89, 289-292. [CrossRef]

244. Zhou, F.; Liang, H.-J.; Di, Y.-L.; You, H.; Zhu, F.-X. Stimulatory effects of sublethal doses of dimethachlon on Sclerotinia sclerotiorum. Plant Dis. 2014, 98, 1364-1370. [CrossRef]

245. Dixon, A.F.G. Aphid Ecology; Chapman \& Hall: London, UK, 1998.

246. Czylok, A.; Gorczyca, J.; Hałaj, R.; Klimaszewski, S.M.; Wojciechowski, W. Fauna mszyc (Homoptera, Aphidodea) zwałowisk odpadów węglowych i cynkowych województwa katowickiego. Acta Biol. Siles 1991, 18, 108-117.

247. Baker, A.J.M.; Ernst, W.H.O.; van der Ent, A.; Malaisse, F.; Ginocchio, R. Metallophytes: The unique biological resource, its ecology and conservational status in Europe, central Africa and Latin America. In Ecology of Industrial Pollution; Batty, L.C., Hallberg, K.B., Eds.; Cambridge University Press: Cambridge, UK, 2010; pp. 7-40, ISBN 978-0-511-80556-1.

248. Wierzbicka, M.; Rostański, A. Microevolutionary changes in ecotypes of calamine waste heap vegetation near Olkusz, Poland: A review. Acta Biol. Cracoviensia Ser. Bot. 2002, 44, 7-19.

249. Osiadacz, B.; Hałaj, R. Aphids under stress. Species groups and ecological functional groups of aphids define heavy metal grasslands of Central Europe. Redia 2016, 35-51. [CrossRef]

250. Mackoś-Iwaszko, E. Arthropods settling Crataegus xmedia Bechst. in the landscape of Lublin City (South-Eastern Poland). Aphids Other Hemipterous Insects 2012, 18, 71-82.

251. Mackoś-Iwaszko, E.; Lubiarz, M.; Karczmarz, K. The impact of urban conditions on the occurance of aphids on Acer platanoides L. Acta Sci. Pol. Hortorum Cultus 2015, 14, 189-207.

252. Bahadorani, S.; Hilliker, A.J. Biological and behavioral effects of heavy metals in Drosophila melanogaster adults and larvae. J. Insect Behav. 2009, 22, 399-411. [CrossRef]

253. Clements, W.H. Metal tolerance and predator-prey interactions in benthic macroinvertebrate stream communities. Ecol. Appl. 1999, 9, 1073-1084. [CrossRef] 